\title{
Reconstructing the natural hydrology of the San Francisco Bay-Delta watershed
}

\author{
P. Fox ${ }^{1}$, P. H. Hutton ${ }^{2}$, D. J. Howes ${ }^{3}$, A. J. Draper ${ }^{4}$, and L. Sears ${ }^{5}$ \\ ${ }^{1}$ Independent Consulting Engineer, Rockledge, FL, USA \\ ${ }^{2}$ Metropolitan Water District of Southern California, Sacramento, CA, USA \\ ${ }^{3}$ Irrigation Training and Research Center, BioResource and Agricultural Engineering Department, California Polytechnic \\ State University, San Luis Obispo, CA, USA \\ ${ }^{4}$ MWH Americas Inc., 3321 Power Inn Road, Suite 300, Sacramento, CA 95826, Sacramento, CA, USA \\ ${ }^{5}$ Independent researcher, Beaverton, OR, USA \\ Correspondence to: D. J. Howes (djhowes@calpoly.edu)
}

Received: 20 March 2015 - Published in Hydrol. Earth Syst. Sci. Discuss.: 13 April 2015

Revised: 26 September 2015 - Accepted: 29 September 2015 - Published: 22 October 2015

\begin{abstract}
We evaluated the impact of landscape changes on the amount of delta outflow reaching San Francisco Bay. The natural landscape was reconstructed and water balances were used to estimate the long-term annual average delta outflow that would have occurred under natural landscape conditions if the climate from 1922 to 2009 were to repeat itself. These outflows are referred to as natural delta outflows and are the first published estimate of natural delta outflow. These natural delta outflows were then compared with current delta outflows for the same climate and existing landscape, including its re-engineered system of reservoirs, canals, aqueducts, and pumping plants.

This analysis shows that the long-term, annual average delta outflow under current conditions is consistent with outflow under natural landscape conditions. The amount of water currently used by farms, cities, and others is about equal to the amount of water formerly used by native vegetation. Development of water resources in California's Central Valley transferred water formerly used by native vegetation to new beneficial uses without substantially reducing the longterm annual average supply to the San Francisco Bay-Delta estuary. Based on this finding, it is unlikely that observed declines in native freshwater aquatic species are the result of annual average delta outflow reductions.
\end{abstract}

\section{Introduction}

The San Francisco Estuary, composed of San Francisco Bay and the Sacramento-San Joaquin River delta, is the largest estuary along the Pacific coast of the USA and the home to a rich ecosystem. The delta serves as one of the principal hubs of California's water system, which delivers $45 \%$ of the water used statewide to 25 million residents and $16000 \mathrm{~km}^{2}$ of farmland.

The Central Valley in California is a 60 to $100 \mathrm{~km}$ wide broad flat alluvial plain, stretching over $750 \mathrm{~km}$ from north to south and covering about $58000 \mathrm{~km}^{2}$ (containing the irrigated land from south of Redding to south of Bakersfield in Fig. 1). This valley is entirely surrounded by mountains except for a narrow gap on its western edge through which the combined Sacramento and San Joaquin rivers flow to the Pacific Ocean through San Francisco Bay (Fig. 1). This valley is the agricultural heartland of the USA, producing over 360 products and more than half of the country's vegetables, fruits and nuts. It is often considered the most productive agricultural region in the world, a status achieved by significantly re-engineering the natural landscape. The tributary watersheds in the northern portion of the Central Valley, referred to in this work as the valley floor (Fig. 2), are the major sources of freshwater to the San Francisco Bay-Delta system. The Sacramento River from the north and the San Joaquin River from the south flow toward each other, joining in the delta. 


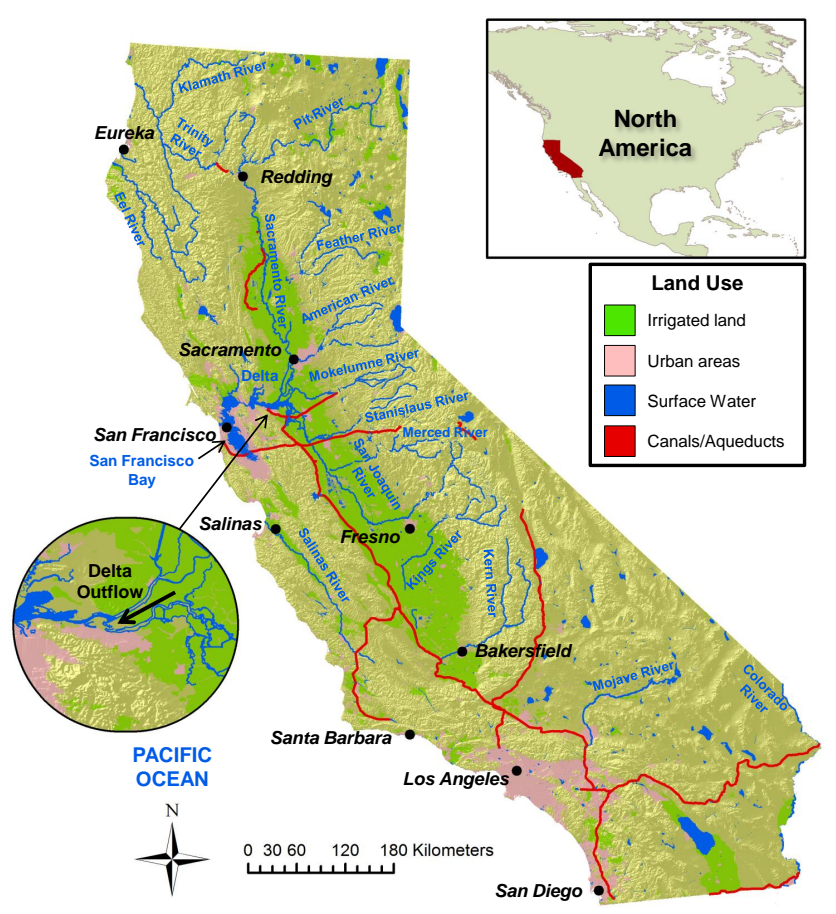

Figure 1. California, current land classifications, and major tributaries feeding into and through the Central Valley.

The development of California from small-scale human settlements that co-existed with an environment rich in native vegetation to the eighth largest economy in the world was facilitated by reconfiguring the state's water resources to serve new uses: agriculture, industry, and a burgeoning population. The redistribution of water from native vegetation to other uses was accompanied by significant declines in native aquatic species that rely on the San Francisco Bay-Delta system. Declines in native aquatic species have been documented in the San Francisco Bay-Delta system over the last several decades (Jassby et al., 1995; MacNally et al., 2010; Thomson et al., 2010). Many aquatic species have been classified as endangered, threatened, and species of concern, e.g., Sacramento River winter-run Chinook salmon, delta smelt, Sacramento splittail, longfin smelt, southern green sturgeon (Lund et al., 2007). These declines have been attributed to several factors including reduced volume and altered timing of freshwater flows from the tributary watersheds (delta outflow), decreased sediment loads, increased nutrient loads, changes in nutrient stoichiometry, contaminants, introduced species, habitat degradation and loss, and shifts in the oceanatmosphere system (Luoma and Nichols, 1993; Jassby et al., 1995; Bennett and Moyle, 1996; MacNally et al., 2010; Glibert, 2010; Glibert et al., 2011; Miller et al., 2012; Cloern and Jassby, 2012).

The native species of concern evolved and thrived under natural landscape conditions, or those that existed prior to European settlement starting in the mid-18th century. These

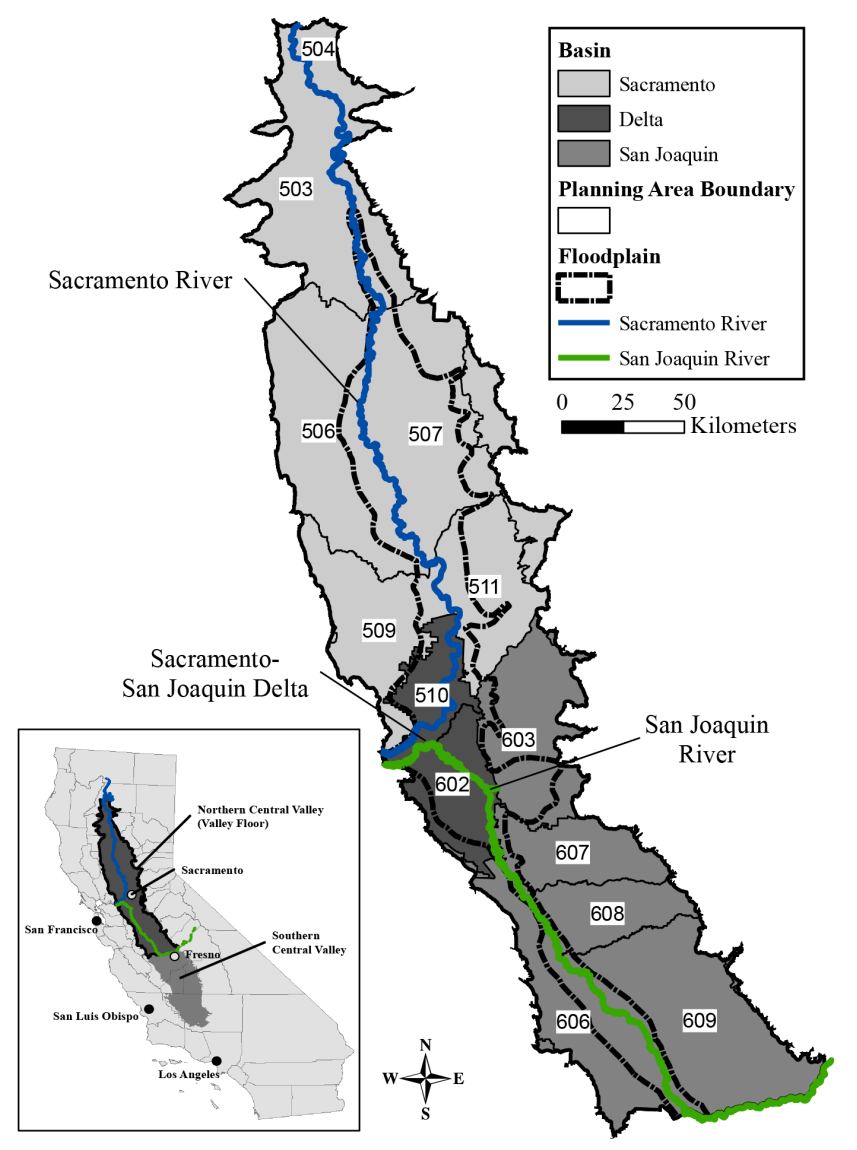

Figure 2. Valley floor study area showing the area where water use calculations were conducted by planning area and summarized by hydrologic basin. Planning areas 502, 505, 508, 601, 604, 605 and 610 within the valley floor are too small to show on this map. Planning area boundaries were defined by CDWR (2005a, b).

undisturbed conditions are referred to in this work as natural conditions, meaning undisturbed by western civilization. Thus, natural delta outflows are those that would have occurred with natural landscape conditions.

The natural landscape included immense inland marshes located in natural flood basins along major rivers (Alexander et al., 1874; Hall, 1887; Garone, 2011), lush riparian forests on river levees (Katibah, 1984), and vast swaths of grasslands interwoven with vernal pools and immense valley oaks in park-like savannas that extended from the floodplains to the oak- and pine-covered foothills (Holland, 1978; Burcham, 1957; Dutzi, 1978). This landscape was fed by periodic overflows of the rivers into natural flood basins along the major rivers. Figure 3 is an idealized cross section through the valley floor that illustrates the major features of this natural landscape. This landscape was dramatically altered, starting in the mid-18th century, to support new land and water uses. The native vegetation was largely replaced by cultivated crops, the flood basins were drained, the rivers were confined between levees, headwater reservoirs were built to store 


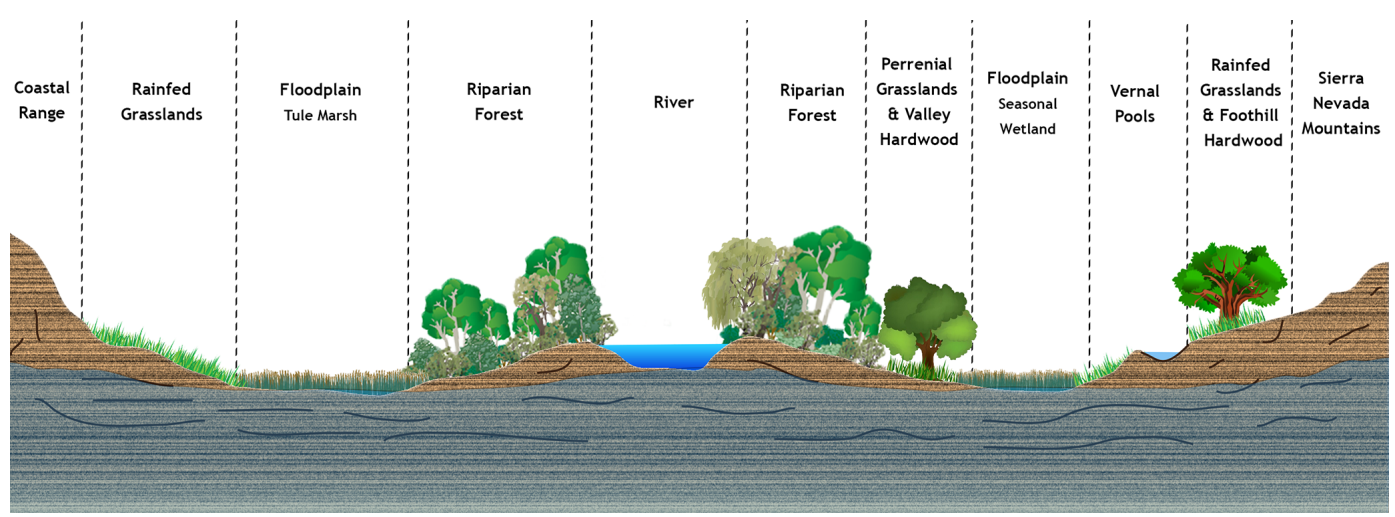

Figure 3. Idealized cross section of the valley floor under natural conditions.

floodwaters, and an extensive system of canals and aqueducts was built to move water from its point of origin to distant locations.

In this study, the hypothesis that current annual average freshwater flows are lower than natural annual average flows into the estuary is tested using a simple water balance, normalized to the contemporary climate. We then compare our natural delta outflow estimate with an estimate of delta outflow that occurs annually under current conditions. This is the first published estimate of natural delta outflow into the San Francisco Bay-Delta estuary. Others have used a surrogate, known as unimpaired flows in California, to estimate natural outflows. As will be demonstrated, the surrogate fails to account for evapotranspiration by native vegetation, the major consumptive use of water in the natural system, resulting in a significant overestimate of natural delta outflows.

\section{Study area background}

Prior to development, starting in the mid-18th century, the channels of the major rivers did not have adequate capacity to carry normal winter rainfall runoff and spring snowmelt (Grunsky, 1929; California State Engineer, 1908). The rivers overflowed their banks into vast natural flood basins flanking both sides of the Sacramento and San Joaquin rivers (Hall, 1880; Grunsky, 1929). Sediment deposited as the rivers spread out over the floodplain and built up natural levees along the river channels. These natural levees were much larger and more developed along the Sacramento River than along the San Joaquin River (Hall, 1880).

The natural levees were lined with lush riparian forest. The floodplains contained large expanses of tule marsh, seasonal wetlands, vernal pools, grasslands, lakes, sloughs, and other landforms that slowed the passage of flood waters (Whipple et al., 2012; Garone, 2011; Holmes and Eckmann, 1912). Groundwater generally moved from recharge areas along the sides of the valley towards topographically lower areas in the central part of the valley, where it was depleted through marsh, vernal pool, and riparian forest evapotranspiration (TBI, 1998; Bertoldi et al., 1991; Williamson et al., 1989; Davis et al., 1959).

Grasslands interspersed with vernal pools (seasonal wetlands) stretched from the edge of the floodplain to the foothills, generally overlying relatively impermeable hardpans and claypans that supported perched water tables. This habitat once occupied nearly all level lands between the foothills and floodplain and was the dominant vegetation under natural conditions, supplied by perched aquifers, overland runoff from the foothills, and precipitation.

This natural landscape, summarized in Fig. 4, was radically modified, starting in the mid-18th century, to make it suitable for agricultural (Smith and Verrill, 1998) and urban uses, creating the world's largest water system supporting the eighth largest economy in the world. The native vegetation was removed, river channels were dredged and rip rapped, levees were raised, the flood basins were drained, bypasses were installed to route flood waters directly into the delta, and head-stream reservoirs were built to replace sidestream storage, provide protection from floods, and generate electricity. Massive hydraulic works were built to move water from areas of relative abundance to areas of relative scarcity throughout the state, including Los Angeles and the San Francisco Bay Area. The history of these changes have been documented elsewhere (Kelley, 1959, 1989; Bain et al., 1966; Kahrl, 1979; Thompson, 1957; Hundley, 2001; Olmstead and Rhode, 2004; CDWR, 2013b).

\section{Methods}

Annual average delta outflow was estimated under natural landscape conditions (natural delta outflow) using a conventional water balance. The results of this calculation are compared with two estimates of delta outflow by the California Department of Water Resources (CDWR): (1) current delta outflow (CDWR, 2012) and (2) unimpaired delta outflow (CDWR, 2007). CDWR's unimpaired outflow calculation re- 

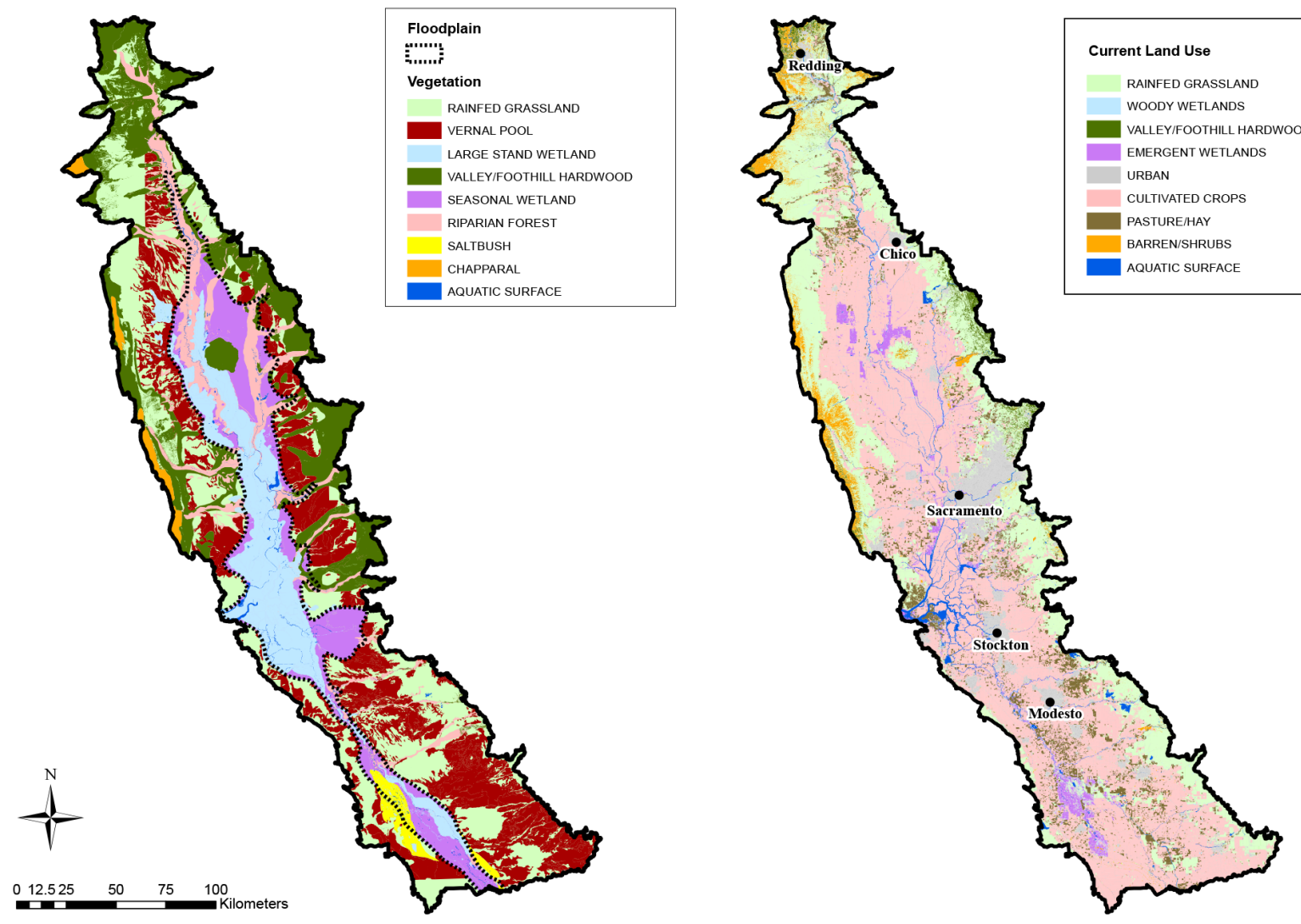

Figure 4. Natural vegetation in the valley floor map portraying the areal extent of natural vegetation based on the Case I definition of grassland composition (i.e., all grassland area outside of the floodplain was classified as either vernal pool or rainfed grassland). Although this map represents a composite of several maps, the primary source of information comes from CSU Chico's pre-1900 Historic Vegetation Map (CSU Chico, 2003) (left panel). Current land use on the valley floor (right panel).

moves the impacts of most upstream alterations from the observed hydrologic record. However, the calculation does not remove alterations such as channel improvements, levees, and flood bypasses. As a result, the calculation assumes that rim inflows from the surrounding mountain ranges are routed through the existing system of channels and bypasses in the delta with little or no interaction with the natural landscape (CDWR, 2007). These unimpaired outflows are frequently misused as a surrogate for natural delta outflow (Cloern and Jassby, 2012; Dynesius and Nilsson, 1994). All three of these estimates are based on the level of development methodology and the climate over the period 1922 to 2009 to facilitate direct comparisons.

\subsection{Level of development methodology}

These three estimates of delta outflow - natural, current and unimpaired - were estimated using a synthetic multi-year hydrologic sequence utilizing a level of development approach (Draper et al., 2004). This method routes the same amount of water (rim inflows plus precipitation) over a defined historical period assuming frozen conditions such as land use, flood control and water supply facility operations, and environmental regulations. In other words, this method simulates river flows under a repeat of historical climate, but holding land use and facility operations constant.

A historical hydrologic sequence may be generated to represent development as it existed in a particular year (i.e., 1990 level of development), as it exists today (i.e., current level of development), or as it may exist under a projected scenario (i.e., future level of development). This approach allows us to estimate the impact of anthropogenic changes on natural delta outflow by comparing a natural level of development with a current level of development.

Thus, our estimate of natural outflow is not an estimate of actual flows that occurred under Paleolithic or more recent conditions prior to European settlement (Ingram et al., 1996; Malamud-Roam et al., 2006; Meko et al., 2001). Rather, our natural delta outflow calculation is an estimate that assumes the contemporary precipitation and inflow pattern to the valley floor with the valley floor in a natural or undeveloped state: before flood control facilities, levees, land reclamation, irrigation projects, imports, etc. 
Natural outflow calculations were performed on a monthly basis assuming long-term climatic conditions observed over an 88-year period (1922 to 2009). The calculations assume a conventional California October through September water year. Water balances were calculated around the portion of the Central Valley that drains into San Francisco Bay (referred to as the valley floor) as shown in Fig. 2.

\subsection{Natural delta outflow}

Natural delta outflow was calculated using a conventional water balance as the difference between water supply and water use:

natural delta outflow $=$ water supply - water use.

Natural delta outflows are the outflows that would result if the climate for the period 1922 to 2009 were to occur under natural landscape conditions. Natural landscape conditions are those that existed prior to the advent of European settlement, starting in the mid-18th century, including native vegetation (Fig. 4) and natural landforms such as stream-side flood basins and low levees.

The water supply is the sum of rim inflows from the surrounding mountain ranges into the valley floor plus precipitation on the valley floor, adjusted to remove impairments such as diversions. The only losses of water under natural conditions were evaporation from water surfaces and evapotranspiration by native vegetation. Water that is not evaporated or evapotranspired flows out of the delta into San Francisco Bay and is referred to here as delta outflow.

Equation (1) assumes that the long-term, annual average change in groundwater storage would have been zero under pre-development conditions. This assumption would not significantly affect long-term annual average calculations as the year-to-year fluctuations of groundwater exchanges are insignificant compared to average surface water flows. However, it would affect seasonal flow patterns, which is the subject of ongoing work. Net groundwater depletions under predevelopment conditions are approximately zero and unimportant to the overall annual water balance (Gleick, 1987).

Water balances are reported for three hydrologic regions that comprise the valley floor: the Sacramento Basin, the San Joaquin Basin, and the delta (Fig. 2). Water balances were calculated at a finer resolution for 16 subsets of the valley floor, referred to as "planning areas" (CDWR, 2005a, b) shown on Fig. 2.

The results of these conventional water balance calculations are compared with current delta outflow (CDWR, 2012) and a surrogate for natural outflow, unimpaired outflow (CDWR, 2007), estimated based on the level of development methodology.

\subsection{Natural water supply}

The water supply used in the natural water balances was estimated as the sum of rim inflows around the periphery of the valley floor plus precipitation that falls on the valley floor. The long-term annual average natural water supply is 50.1 billion $\mathrm{m}^{3} \mathrm{yr}^{-1}$, comprising 34.2 billion $\mathrm{m}^{3} \mathrm{yr}^{-1}$ from rim inflows and 15.9 billion $\mathrm{m}^{3} \mathrm{yr}^{-1}$ from precipitation over the valley floor.

The valley floor boundary is defined by the drainage basins of the gages used to determine valley rim inflows, adjusted (i.e., unimpaired) to remove the effects of upstream storage regulation, imports, and exports. Rim inflows are defined as the natural water supply from the surrounding mountains and other watersheds to the valley floor. The rim inflows were compiled for undeveloped and developed watersheds from several sources that cover different portions of the study area.

Rim inflows have been affected by changes in land use and forest management and by loss of natural meadows. Agricultural and urban development represents a relatively small portion (about five percent) of the rim watersheds. While low elevation hardwoods and chaparral have been lost and annual grassland areas have increased (Thorne et al., 2008), much of the rim watersheds remain characterized by conifer forest. Forest management practices, which have resulted in denser forest stands compared to pre-development conditions, may significantly affect runoff timing and volume (Bales et al., 2011; CDWR, 2013b). Denser forest canopy prevents snow from reaching the ground and leads to greater evapotranspiration and earlier snowmelt (CDWR, 2013b). However, scientific evidence necessary to quantify relationships between forest management and water supply has been inconclusive. Therefore, our work assumes natural inflows from the rim watersheds are equal to historical inflows adjusted to remove the effects of upstream storage regulation, imports, and exports (i.e., unimpaired inflows).

Historical flow records were generated from US Geological Survey (USGS) and California Department of Water Resources (CDWR) gage data and extended through linear correlation with gaged flows in nearby watersheds. Rim inflows from ungaged watersheds were estimated from adjacent gaged watersheds based on relative drainage area and average annual precipitation.

Unimpaired flows (CDWR, 2013a) from developed rim watersheds in the Sacramento and San Joaquin hydrologic regions were assumed to equal natural inflows. Similarly, unimpaired flows from the rim watershed south of the valley floor (i.e., the Tulare Lake hydrologic region) were assumed to be equal to natural inflows (CDWR, 2012). Minimal groundwater flow from the Sierra Nevada and Coastal Range to the valley floor is assumed, due to the presence of bedrock and high surface slopes (Armstrong and Stidd, 1967; Gleick, 1987; Williamson et al., 1989).

In addition to rim inflows from surrounding mountain watersheds, precipitation falling directly on the valley floor con- 
tributes to the water supply. Precipitation was calculated for each planning area within the valley floor using distributed grids obtained from the PRISM Climate Group at Oregon State University (Daly et al., 2000; Daly and Bryant, 2013; PRISM Climate Group, 2013).

\subsection{Natural water use}

The pre-development valley floor was a diverse ecosystem of immense inland marshes, lush riparian forests, and vast swaths of grasslands interwoven with vernal pools and immense valley oaks in park-like savannas that extended from the floodplains to the oak- and pine-covered foothills (Bryan, 1923; Davis et al., 1959; Thompson, 1961, 1977; Roberts et al., 1977; Dutzi, 1978; Warner and Hendrix, 1985; TBI, 1998; Cunningham, 2010; Garone, 2011; Whipple et al., 2012).

Under natural conditions, the only water use was evapotranspiration by natural vegetation and evaporation from water surfaces such as lakes, rivers, and sloughs. We estimated the amount of water used by natural vegetation from the areal extent and evapotranspiration rate for each type of vegetation. We also estimated evaporation from lakes, rivers, and sloughs based on the area and evaporation rates from these bodies of water.

Estimating the water used by natural vegetation (ET) requires information on the vegetation evapotranspiration rate $\left(\mathrm{ET}_{\mathrm{v}}\right)$ and the areal extent of vegetation $\left(A_{\mathrm{v}}\right)$. The volume of water used by natural vegetation is then estimated in Eq. (2) as the product of $\mathrm{ET}_{\mathrm{v}}$ and $A_{\mathrm{v}}$ summed over all planning areas $i$ and vegetation types $j$ :

$\mathrm{ET}=\sum_{i, j}\left(\mathrm{ET}_{\mathrm{v}} \times A_{\mathrm{v}}\right)$.

The same method was applied to evapotranspiration from free water surfaces such as lakes, ponds, sloughs, and river channels. The remainder of the section discusses how $\mathrm{ET}_{\mathrm{v}}$ and $A_{\mathrm{v}}$ were estimated.

\subsubsection{Evapotranspiration}

The reference crop method was used to estimate evapotranspiration by natural vegetation (Howes and Pasquet, 2013; Howes et al., 2015). As shown in Eq. (3), the evapotranspiration rate is related to the grass reference evapotranspiration $\left(\mathrm{ET}_{\mathrm{o}}\right)$ for a standardized grass reference crop grown under idealized conditions multiplied by a vegetation coefficient $\left(K_{\mathrm{v}}\right)$ that accounts for canopy/plant characteristics:

$\mathrm{ET}_{\mathrm{v}}=\mathrm{ET}_{\mathrm{o}} \times K_{\mathrm{v}}$.

Two methods were used to estimate $K_{\mathrm{v}}$, depending upon the available water supply used by various vegetation categories. The methods used to develop the $K_{\mathrm{v}}$ and $\mathrm{ET}_{\mathrm{v}}$ used in this study are discussed in detail in Howes et al. (2015). The methods are briefly summarized in the following sections.
For non-stressed vegetation with a continuous water supply throughout the growing season, $K_{\mathrm{v}}$ was estimated from published studies of actual monthly (or more frequent) $\mathrm{ET}_{\mathrm{v}}$ using a grass reference evapotranspiration $\left(\mathrm{ET}_{\mathrm{O}}\right.$ ) (Howes et al., 2015). The $\mathrm{ET}_{\mathrm{o}}$ used to derive the $K_{\mathrm{V}}$ values for this study was computed using the Standardized PenmanMonteith equation (Allen et al., 2005) when a full set of meteorological data were available; otherwise, the Hargreaves equation was used. The accuracy of this method was confirmed for permanent wetlands and riparian forest using actual evapotranspiration measured using remote sensing at two sites in central California (Howes et al., 2015).

For vegetation depending solely on precipitation (chaparral and a portion of the grasslands and valley/foothill hardwood), a daily soil water balance using the dual-crop coefficient method (Allen et al., 1998) was used to estimate $\mathrm{ET}_{\mathrm{v}}$ and $K_{\mathrm{V}}$ over the 88-year study period (Howes et al., 2015). The $\mathrm{ET}_{\mathrm{v}}$ values directly from the daily soil water balance were used in Eq. (2) for vegetation types reliant solely on precipitation. Since the daily soil water balance accounts for variable precipitation, the $\mathrm{ET}_{\mathrm{v}}$ from vegetation reliant on precipitation varies from year to year. As a reference, the longterm annual average $K_{\mathrm{v}}$ values for these vegetation types were calculated from daily soil water balances for each planning area and are summarized in Table 1.

The $K_{\mathrm{v}}$ values summarized in Table 1 for non-water stressed vegetation were used in Eq. (3) to estimate monthly average $\mathrm{ET}_{\mathrm{v}}$ for vegetation types that had access to full yearround water supply by planning area. Long-term average $\mathrm{ET}_{\mathrm{V}}$ values for all vegetation types are shown in Table 2 (Howes et al., 2015).

\subsubsection{Vegetation areas}

The vegetation present on the valley floor under natural conditions included rainfed and perennial grasslands, vernal pools, permanent and seasonal wetlands, valley/foothill hardwood, riparian forest, saltbush, and chaparral (Howes et al., 2015; Barbour et al., 1993; Garone, 2011; Küchler, 1977). The areal extent of each type of vegetation was estimated from historic maps and contemporary estimates based on historic sources (Hall, 1887; Burcham, 1957; Küchler, 1977; Roberts et al., 1977; Dutzi, 1978; Fox, 1987; TBI, 1998; CSU Chico, 2003; Garone, 2011; Whipple et al., 2012; Fox and Sears, 2014), supplemented by early soil surveys for vernal pools (Holmes et al., 1915; Nelson et al., 1918; Strahorn et al., 1911; Lapham et al., 1904, 1909; Sweet et al., 1909; Holmes and Eckmann, 1912; Mann et al., 1911; Lapham and Holmes, 1908; Watson et al., 1929).

Most of these vegetation maps focused on a single type of vegetation, so we were unable to use them as our primary source. Further, we were unable to piece the more limited coverage maps together in any meaningful way as they used different vegetation classification systems and different study areas; even this collection of maps did not cover the entire 
Table 1. Monthly vegetation coefficients $\left(K_{\mathrm{V}}\right)$ for non-water stressed and rainfed vegetation (Howes et al., 2015).

\begin{tabular}{|c|c|c|c|c|c|c|c|c|c|c|c|c|}
\hline \multirow[b]{2}{*}{ Vegetation } & \multicolumn{12}{|c|}{ Month } \\
\hline & Jan & Feb & Mar & Apr & May & Jun & Jul & Aug & Sep & Oct & Nov & Dec \\
\hline Rainfed grassland* & 0.78 & 0.72 & 0.64 & 0.58 & 0.35 & 0.06 & 0.00 & 0.00 & 0.03 & 0.16 & 0.47 & 0.73 \\
\hline Perennial grassland & 0.55 & 0.55 & 0.60 & 0.95 & 1.00 & 1.05 & 1.10 & 1.15 & 1.10 & 1.00 & 0.85 & 0.85 \\
\hline Vernal pool & 0.65 & 0.70 & 0.80 & 1.00 & 1.05 & 0.85 & 0.50 & 0.15 & 0.10 & 0.10 & 0.25 & 0.60 \\
\hline Large stand wetland & 0.70 & 0.70 & 0.80 & 1.00 & 1.05 & 1.20 & 1.20 & 1.20 & 1.05 & 1.10 & 1.00 & 0.75 \\
\hline Small stand wetland & 1.00 & 1.10 & 1.50 & 1.50 & 1.60 & 1.70 & 1.90 & 1.60 & 1.50 & 1.20 & 1.15 & 1.00 \\
\hline Foothill hardwood* & 0.80 & 0.77 & 0.69 & 0.61 & 0.52 & 0.20 & 0.01 & 0.01 & 0.03 & 0.15 & 0.46 & 0.71 \\
\hline Valley oak savanna* & 0.80 & 0.77 & 0.69 & 0.62 & 0.54 & 0.40 & 0.40 & 0.40 & 0.40 & 0.41 & 0.55 & 0.71 \\
\hline Seasonal wetland & 0.70 & 0.70 & 0.80 & 1.00 & 1.05 & 1.10 & 1.10 & 1.15 & 0.75 & 0.80 & 0.80 & 0.75 \\
\hline Riparian forest & 0.80 & 0.80 & 0.80 & 0.80 & 0.90 & 1.00 & 1.10 & 1.20 & 1.20 & 1.15 & 1.00 & 0.85 \\
\hline Saltbush & 0.30 & 0.30 & 0.30 & 0.35 & 0.45 & 0.50 & 0.60 & 0.55 & 0.45 & 0.35 & 0.40 & 0.35 \\
\hline Chaparral* $^{*}$ & 0.55 & 0.61 & 0.54 & 0.40 & 0.22 & 0.03 & 0.01 & 0.01 & 0.03 & 0.14 & 0.40 & 0.57 \\
\hline Aquatic surface & 0.65 & 0.70 & 0.75 & 0.80 & 1.05 & 1.05 & 1.05 & 1.05 & 1.05 & 1.00 & 0.80 & 0.60 \\
\hline
\end{tabular}

* Evapotranspiration from rainfed vegetation was estimated from a daily soil water balance. Valley oak savanna $K_{\mathrm{V}}$ during the summer and fall was estimated to be 0.4 to account for groundwater contribution. The vegetation coefficients shown are averages over the 88 -year period and all valley floor planning areas.

Table 2. Annual average evapotranspiration rates $\mathrm{ET}_{\mathrm{V}}\left(\mathrm{cm} \mathrm{yr}^{-1}\right)$.

\begin{tabular}{|c|c|c|c|c|c|c|c|c|c|c|c|c|c|}
\hline Basin & $\begin{array}{c}\text { Planning } \\
\text { area }\end{array}$ & $\begin{array}{l}\text { Rainfed } \\
\text { grassland }\end{array}$ & $\begin{array}{l}\text { Perennial } \\
\text { grassland }\end{array}$ & $\begin{array}{c}\text { Vernal } \\
\text { pool }\end{array}$ & $\begin{array}{c}\text { Large } \\
\text { stand } \\
\text { wetland }\end{array}$ & $\begin{array}{c}\text { Small } \\
\text { stand } \\
\text { wetland }\end{array}$ & $\begin{array}{c}\text { Seasonal } \\
\text { wetland }\end{array}$ & $\begin{array}{c}\text { Foothill } \\
\text { hardwood }\end{array}$ & $\begin{array}{c}\text { Valley } \\
\text { oak } \\
\text { savanna }\end{array}$ & $\begin{array}{c}\text { Riparian } \\
\text { forest }\end{array}$ & Saltbush & Chaparral & $\begin{array}{l}\text { Aquatic } \\
\text { surface }\end{array}$ \\
\hline \multirow{8}{*}{ 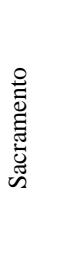 } & 502 & 39.1 & 130.1 & 75.3 & 139.5 & 204.3 & 131.1 & 45.1 & 67.1 & 134.1 & 60.2 & 29.5 & 127.4 \\
\hline & 503 & 39.1 & 130.1 & 75.3 & 139.5 & 204.3 & 131.1 & 45.1 & 67.1 & 134.1 & 60.2 & 29.5 & 127.4 \\
\hline & 504 & 34.0 & 128.9 & 73.9 & 137.8 & 201.7 & 129.4 & 40.2 & 64.0 & 132.5 & 59.6 & 28.8 & 125.8 \\
\hline & 505 & 32.8 & 135.9 & 77.9 & 145.1 & 212.5 & 136.2 & 40.2 & 67.1 & 139.6 & 62.7 & 24.7 & 132.5 \\
\hline & 506 & 32.4 & 135.0 & 77.7 & 144.2 & 211.3 & 135.5 & 39.8 & 67.1 & 138.7 & 62.3 & 25.0 & 131.7 \\
\hline & 507 & 35.2 & 139.2 & 80.1 & 148.7 & 217.9 & 139.7 & 42.7 & 70.1 & 143.0 & 64.3 & 26.9 & 135.8 \\
\hline & 508 & 36.6 & 143.3 & 82.3 & 152.4 & 222.5 & 140.2 & 42.7 & 73.2 & 146.3 & 67.1 & 27.4 & 140.2 \\
\hline & 509 & 32.8 & 135.9 & 77.9 & 145.1 & 212.5 & 136.2 & 40.2 & 67.1 & 139.6 & 62.7 & 24.7 & 132.5 \\
\hline \multirow{2}{*}{ 㞼 } & 510 & 31.2 & 136.8 & 78.5 & 146.0 & 213.8 & 137.0 & 38.6 & 67.1 & 140.4 & 63.1 & 23.2 & 133.3 \\
\hline & 602 & 27.2 & 121.3 & 70.3 & 129.5 & 189.8 & 121.8 & 33.3 & 57.9 & 124.6 & 55.9 & 19.3 & 118.3 \\
\hline \multirow{10}{*}{ 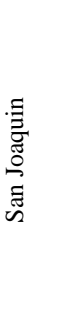 } & 511 & 34.8 & 143.3 & 81.8 & 153.0 & 224.1 & 143.5 & 42.6 & 73.2 & 147.1 & 66.2 & 26.4 & 139.7 \\
\hline & 601 & 27.4 & 113.5 & 65.5 & 121.1 & 177.4 & 113.9 & 32.3 & 54.9 & 116.6 & 52.3 & 19.0 & 110.6 \\
\hline & 603 & 33.7 & 142.7 & 81.9 & 152.3 & 223.3 & 143.0 & 41.5 & 70.1 & 146.4 & 65.9 & 25.5 & 139.1 \\
\hline & 604 & 30.5 & 137.2 & 79.2 & 149.4 & 213.4 & 134.1 & 39.6 & 67.1 & 140.2 & 64.0 & 24.4 & 134.1 \\
\hline & 605 & 24.4 & 134.1 & 79.2 & 146.3 & 213.4 & 134.1 & 30.5 & 61.0 & 140.2 & 64.0 & 18.3 & 131.1 \\
\hline & 606 & 24.0 & 135.6 & 78.4 & 144.7 & 212.1 & 136.1 & 31.2 & 61.0 & 139.2 & 62.6 & 17.4 & 132.2 \\
\hline & 607 & 29.3 & 140.2 & 80.9 & 149.6 & 219.5 & 140.6 & 36.8 & 67.1 & 143.8 & 64.7 & 21.6 & 136.7 \\
\hline & 608 & 28.9 & 144.6 & 83.8 & 154.3 & 226.4 & 145.0 & 36.6 & 70.1 & 148.2 & 66.7 & 21.5 & 141.0 \\
\hline & 609 & 29.0 & 152.1 & 87.5 & 162.2 & 238.0 & 152.2 & 37.2 & 70.1 & 155.8 & 70.2 & 22.0 & 148.2 \\
\hline & 610 & 29.0 & 152.1 & 87.5 & 162.2 & 238.0 & 152.2 & 37.2 & 70.1 & 155.8 & 70.2 & 22.0 & 148.2 \\
\hline
\end{tabular}

valley floor study area. Thus, we based our natural vegetation estimates on the California State University at Chico (CSU Chico) pre-1900 map, which covered most of the valley floor.

The CSU Chico study reviewed and digitized approximately 700 historic maps from numerous collections in public libraries. These sources were pulled together in a series of maps, including a "pre-1900 historic vegetation map". We used the pre-1900 historic vegetation map as our base map, modified to cover the entire valley floor using Küchler (1977) and to further subdivide some of its vegetation classifications to match available evapotranspiration information.
CSU Chico characterized its pre-1900 map as "the best available historical vegetation information for the pre-1900 period" noting it provided "a snapshot of the most likely pre Euro-American vegetation cover" (CSU Chico, 2003). This map has been cited by others as representing natural vegetation (Bolger et al., 2011; Vaghti and Greco, 2007). It is based on a patchwork of sources, scales, and dates, with the earliest source map dating to 1874 .

The accuracy of the CSU Chico pre-1900 map was confirmed to the extent feasible using GIS overlays with other available natural vegetation maps (Hall, 1887; Roberts et al., 1977; Dutzi, 1978; Fox, 1987; TBI, 1998; Garone, 2011; 
Table 3. Area of natural vegetation $\left(A_{\mathrm{V}}\right)$ by planning area within the valley floor, Case $\mathrm{I}(\mathrm{ha})$.

\begin{tabular}{|c|c|c|c|c|c|c|c|c|c|c|c|}
\hline Valley & $\begin{array}{l}\text { Planning } \\
\text { area }\end{array}$ & $\begin{array}{r}\text { Rainfed } \\
\text { grasslands }\end{array}$ & $\begin{array}{r}\text { Vernal } \\
\text { pool }\end{array}$ & $\begin{array}{r}\text { Permanent } \\
\text { wetland }\end{array}$ & $\begin{array}{r}\text { Seasonal } \\
\text { wetland }\end{array}$ & $\begin{array}{r}\text { Valley/ } \\
\text { foothill } \\
\text { hardwood }\end{array}$ & $\begin{array}{r}\text { Riparian } \\
\text { forest }\end{array}$ & Saltbush & Chaparral & $\begin{array}{l}\text { Aquatic } \\
\text { surface }\end{array}$ & Total \\
\hline \multirow{9}{*}{ 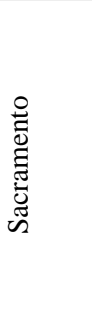 } & 502 & 0 & 0 & 0 & 0 & 692 & 0 & 0 & 0 & 0 & 692 \\
\hline & 503 & 114308 & 25046 & 7 & 2 & 130205 & 33271 & 0 & 7478 & 1253 & 311570 \\
\hline & 504 & 52570 & 433 & 96 & 977 & 78027 & 34720 & 0 & 39 & 807 & 167667 \\
\hline & 505 & 0 & 0 & 0 & 0 & 31 & 0 & 0 & 2170 & 0 & 2201 \\
\hline & 506 & 140301 & 94683 & 50395 & 19679 & 71054 & 43383 & 0 & 9541 & 2429 & 431466 \\
\hline & 507 & 19523 & 33515 & 60751 & 102700 & 75491 & 80467 & 0 & 0 & 3274 & 375721 \\
\hline & 508 & 7289 & 3712 & 0 & 0 & 86369 & 5407 & 0 & 0 & 590 & 103368 \\
\hline & 509 & 65863 & 42392 & 27454 & 5395 & 58148 & 25913 & 0 & 22000 & 610 & 247775 \\
\hline & 511 & 18066 & 74895 & 20989 & 25425 & 51101 & 17408 & 0 & 0 & 3116 & 211000 \\
\hline \multirow{2}{*}{$\begin{array}{l}\frac{\pi}{\mathscr{\Xi}} \\
\stackrel{\Xi}{0}\end{array}$} & 510 & 718 & 4263 & 91810 & 10550 & 21 & 760 & 0 & 0 & 5240 & 113361 \\
\hline & 602 & 25265 & 8533 & 115385 & 9128 & 34 & 594 & 0 & 0 & 2858 & 161798 \\
\hline \multirow{9}{*}{ 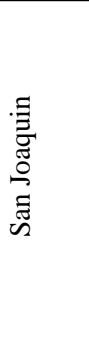 } & 601 & 3885 & 3874 & 0 & 2 & 0 & 1 & 0 & 0 & 274 & 8037 \\
\hline & 603 & 47777 & 59435 & 5117 & 55734 & 80998 & 16614 & 0 & 157 & 629 & 266461 \\
\hline & 604 & 1098 & 0 & 0 & 0 & 741 & 311 & 0 & 0 & 0 & 2149 \\
\hline & 605 & 4924 & 406 & 0 & 0 & 0 & 0 & 0 & 0 & 0 & 5331 \\
\hline & 606 & 83099 & 70915 & 12084 & 57570 & 0 & 1281 & 41405 & 32 & 1136 & 267523 \\
\hline & 607 & 69411 & 64097 & 3295 & 9099 & 1355 & 10574 & 0 & 0 & 820 & 158651 \\
\hline & 608 & 66786 & 51142 & 3037 & 4945 & 1689 & 12797 & 0 & 0 & 478 & 140873 \\
\hline & 609 & 123728 & 242041 & 17323 & 18450 & 501 & 8462 & 8099 & 0 & 1258 & 419863 \\
\hline & 610 & 6547 & 376 & 0 & 0 & 67 & 4 & 0 & 0 & 0 & 6995 \\
\hline \multicolumn{2}{|c|}{ Total } & 851158 & 779758 & 407744 & 319657 & 636525 & 291966 & 49505 & 41416 & 24771 & 3402501 \\
\hline
\end{tabular}

Note: Case I assumes (1) no perennial grasslands, (2) all permanent wetlands are large stand, and (3) all valley/foothill hardwoods are foothill hardwoods.

Whipple et al., 2012). Original shapefiles were used where available (Whipple et al., 2012; TBI, 1998; Küchler, 1977; CSU Chico, 2003). Other maps were scanned (400 dpi full color scanner), the scanned versions were georeferenced using various data layers (e.g., county, township), and the map features were digitized by hand using editing features in ArcMap. ArcMap (ArcGIS 10.1, ESRI, Redlands, CA) geoprocessing tools were used to determine vegetation areas (Fox and Sears, 2014).

The natural vegetation areas estimated using these methods were also compared with those estimated by others. This work estimated about 0.40 million ha of permanent wetlands. Others have estimated 0.40 (Fox 1987) to 0.53 million ha (Hilgard, 1884; Shelton, 1987) for slightly different valley floor boundaries. This work estimated about 1.62 million hectares of grasslands. Others have estimated 2.02 (TBI, 1998) to 2.18 (Fox, 1987; Shelton, 1987) million ha for slightly different valley floor boundaries. The current study estimated approximately 0.77 million ha of vernal pool habitat in the valley floor outside of the floodplain. Others have estimated about 0.97 million ha of vernal pool habitat (Holland, 1978, 1998, 2013; Holland and Hollander, 2007) for slightly different valley floor boundaries. This work also estimated 0.29 million ha of riparian forest based on CSU Chico's map, which is low compared to estimates by others including $0.35,0.38,0.37,0.58$, and 0.65 million ha es- timated by Shelton (1987), Roberts et al. (1977), Katibah (1984), Fox (1987), and Warner and Hendrix (1985), respectively, for slightly different valley floor boundaries.

However, as the CSU Chico maps and other sources were based on maps prepared after significant modifications to the landscape had already occurred, they may underestimate some types of natural vegetation (Thompson, 1957; Whipple et al., 2012; CSG, 1862). It follows that reliance on these maps may underestimate evapotranspiration and thereby overestimate natural delta outflow. Riparian forests, for example, were cleared early to make way for cities and farms and harvested to supply fuel for steamboats traversing the rivers in support of the gold rush (Whipple et al., 2012). Widespread conversion of wetlands into agricultural uses began in the 1850s when they were leveed, drained, cleared, leveled, or filled; water entering them was impounded, diverted, or drained; and sloughs and crevasses closed to dry out the land (Whipple et al., 2012; Frayer et al., 1989; CSG, 1862). The great wheat bonanza that transformed much of the Central Valley into farmland was well underway by 1874 , the date of the earliest historic map in the collection considered by CSU Chico.

The results of our natural vegetation area analysis, based on available historic maps and soil surveys, are summarized in Fig. 4 and Table 3. These areas represent the starting 
point for our natural flow estimate. We call this starting point Case I.

Case I represents long-term annual average conditions. These areas are not representative of individual years due to climate-driven variations, which primarily affected grasslands and wetlands. Area size, especially of rainfed grasslands and vernal pools, likely varied from year to year with the amount of precipitation falling on the valley floor and surrounding mountains.

\subsubsection{Sensitivity analysis}

A sensitivity analysis was performed to address the uncertainty in both natural vegetation areas and evapotranspiration rates. The areal extent of most types of vegetation was not measured or even observed by botanists in its natural state. Further, the water used by some classes of natural vegetation, such as vernal pools and valley oak savannas, has never been measured in the valley floor while the natural water supply is largely based on measurements of rim watershed stream flows or impairments thereof and precipitation. Thus, we formulated a series of cases, in which land use was varied, to explore the range in natural vegetation water use. The cases were selected to address key uncertainties associated with classifying vegetation areas. The eight cases we studied are summarized in Table 4.

As grasslands (including vernal pools) and valley/foothill hardwood classifications represent the greatest portions of the valley floor (see Table 3), our cases focus on these two vegetation classifications. The extent of permanent wetlands, the next largest vegetation classification in the valley floor, was extensively surveyed in the 1850s (CSG, 1856, 1862; Anonymous, 1861; Flushman, 2002; Thompson, 1957) and is considered to be accurately estimated in Case I (Table 3 ). Further, the evapotranspiration from these wetlands has been well studied (Howes et al., 2015). Thus, we have confidence in our estimates of water use by permanent wetlands.

Grasslands occupied about half of the valley floor area or about $16000 \mathrm{~km}^{2}$ out of $34000 \mathrm{~km}^{2}$ (Table 3). The composition of these grasslands (e.g., the fraction that was perennial, rainfed, and vernal pool) is unknown, as rapid and widespread modifications occurred before any botanical study (Heady et al., 1992; Holmes and Rice, 1996; Holstein, 2001; Burcham, 1957; Garone, 2011). Some have attempted to estimate vernal pool area (Holland, 1978, 1998; Holland and Hollander, 2007), but we are not aware of any attempts to estimate the area of perennial and rainfed grasslands.

There is significant controversy over the original composition of grasslands. Some argue pristine grasslands were perennial bunchgrasses (Heady, 1988; Küchler, 1977; Bartolome et al., 2007), while others argue they were dominated by annual forbs (Schiffman, 2007; Holstein, 2001). A discussion of this controversy is provided in Garone (2011). Finally, large expanses of lands classified as grasslands by others (Küchler, 1977; Fox, 1987; TBI, 1998; CSU Chico,
2003) were probably vernal pool seasonal wetlands supported by perched aquifers (Zedler, 2003; Holland and Hollander, 2007; Fox and Sears, 2014). Due to these unknowns and controversies, we used six cases to explore the effect of grassland composition on natural water use, the base case compared to five variants.

In Case I, all grassland areas outside of the floodplain were classified as either vernal pool (based on soil surveys) or rainfed grassland, as shown in Fig. 4 and Table 3. We then varied the rainfed portion to assume it was vernal pool (Case II) and perennial grassland (Case III) to bound the likely range.

These three constant-area grassland cases resulted in many negative San Joaquin Basin annual outflows, mostly in dry and critical years. One explanation for this outcome is that the grasslands may have been predominately rainfed in the San Joaquin Basin since this basin is much drier than the other two. Another explanation is that our water balance model assumed the net change in groundwater storage was zero on a long-term basis, which may not be valid on a yearly and basin-wide basis.

Groundwater that was recharged in wet and above-normal years could have supplied the water needs of natural vegetation in subsequent years. Failure to account for these potential inter-annual sources of water could bias individual year water balances and could result in negative basin outflows for individual years (particularly critical and dry years that follow very wet years). Negative basin annual outflows were primarily limited to the San Joaquin Basin.

Thus, in Case IV, all grasslands in the San Joaquin Basin were classified as rainfed grasslands in an attempt to address this possibility, while grasslands in the Sacramento and delta basins were classified as a mix of vernal pool and perennial as in Case III. A similar consideration led to the classification of seasonal wetlands in the San Joaquin Basin as rainfed grasslands (Case VIII, discussed later).

We also discounted the scenario of grasslands being rainfed valley-wide as unlikely, given that our work and the work of Holland and Hollander (2007) established that a significant fraction of the valley floor was vernal pool habitat. Some of these grassland areas, particularly within the flood basins, were likely seasonal wetlands or lakes and ponds (Whipple et al., 2012) with higher water uses, but we had no basis for estimating these areas.

It was generally assumed that vegetation areas are constant from year to year in cases I to IV, which is reasonable for a long-term annual average. However, this assumption is an oversimplification when applied to individual years because vegetation area likely varied in response to climate, especially the amount and timing of precipitation and resulting riverbank overflow. The floodplain boundary, for example, would have varied significantly depending on the amount and timing of runoff, which would have affected vegetation both inside and outside of the floodplain. In July 1853, for example, engineers surveying a route for a railroad in the San Joaquin Valley reported: "The river [San Joaquin] had 
Table 4. Water balance cases.

\begin{tabular}{|c|c|c|c|}
\hline \multirow[t]{2}{*}{ Case } & \multicolumn{2}{|c|}{ Grassland assumptions } & \multirow{2}{*}{$\begin{array}{l}\text { Hardwood } \\
\text { assumptions }\end{array}$} \\
\hline & Sacramento and Delta Basins & San Joaquin Basin & \\
\hline \multicolumn{4}{|c|}{$\begin{array}{l}\text { Grasslands - } \\
\text { constant area }\end{array}$} \\
\hline I & $\begin{array}{l}\text { Mix of rainfed grassland and } \\
\text { Vernal pools }\end{array}$ & $\begin{array}{l}\text { Mix of rainfed grassland and } \\
\text { Vernal pools }\end{array}$ & Foothill \\
\hline II & Vernal pools & Vernal pools & Foothill \\
\hline III & $\begin{array}{l}\text { Mix of perennial grassland and } \\
\text { Vernal pools }\end{array}$ & $\begin{array}{l}\text { Mix of perennial grassland and } \\
\text { Vernal pools }\end{array}$ & Foothill \\
\hline IV & $\begin{array}{l}\text { Mix of perennial grassland and } \\
\text { Vernal pools }\end{array}$ & Rainfed grassland & Foothill \\
\hline \multicolumn{4}{|c|}{$\begin{array}{l}\text { Grasslands - } \\
\text { variable area }\end{array}$} \\
\hline V & $\begin{array}{l}\text { Mix of rainfed and perennial } \\
\text { grassland and Vernal pools }{ }^{1}\end{array}$ & $\begin{array}{l}\text { Mix of rainfed and perennial } \\
\text { grassland and Vernal pools }{ }^{1}\end{array}$ & Foothill \\
\hline VI & $\begin{array}{l}\text { Mix of rainfed and perennial } \\
\text { grassland }^{2}\end{array}$ & $\begin{array}{l}\text { Mix of rainfed and perennial } \\
\text { grassland }^{2}\end{array}$ & Foothill \\
\hline \multicolumn{4}{|c|}{ Other } \\
\hline VII & $\begin{array}{l}\text { Mix of rainfed grassland and } \\
\text { Vernal pools }\end{array}$ & $\begin{array}{l}\text { Mix of rainfed grassland and } \\
\text { Vernal pools }\end{array}$ & Valley oak savanna \\
\hline VIII & $\begin{array}{l}\text { Mix of perennial grassland and } \\
\text { Vernal pools }\end{array}$ & Rainfed grassland ${ }^{3}$ & Foothill \\
\hline \multicolumn{4}{|c|}{$\begin{array}{l}1 \text { Vegetation areas are identical to Case I, except grassland areas not classified as vernal pools are assumed to be a mix of rainfed and } \\
\text { perennial grassland that varies from year to year based on the annual runoff volume as measured by the Eight River Index (CDWR, 2013a). } \\
\text { Grassland areas are assumed to be perennial in the wettest year, rainfed in the driest year, and for all other years, the mix is assumed to vary } \\
\text { linearly with annual runoff volume between the wettest year and driest year. }{ }^{2} \text { Vegetation areas are identical to Case I, except vernal pools } \\
\text { are assumed to be a mix of rainfed and perennial grassland. Aggregate grasslands are assumed to be perennial in the wettest year, rainfed } \\
\text { in the driest year, and for all other years, the mix is assumed to vary linearly with annual runoff volume between the wettest year and driest } \\
\text { year. }{ }^{3} \text { Vegetation areas are identical to Case IV, except seasonal wetlands within the floodplain are assumed to be rainfed grasslands. }\end{array}$} \\
\hline
\end{tabular}

overflowed its banks, and the valley was one vast sheet of water, from 25 to 30 miles broad, and approaching within four to five miles of the hills" (Williamson, 1853). The average floodplain boundary (CDPW, 1931a, b) was typically over 20 miles from these hills. We used the average floodplain boundary to estimate some vegetation types, such as seasonal wetlands within "other floodplain habitat", which would yield inaccuracies when used for individual years.

Grasslands are the vegetation type most likely to respond significantly to climate. Thus, in Cases V and VI, the mix of rainfed and perennial grasslands was varied based on the volume of rim inflow to the Sacramento and San Joaquin basins. Vegetation areas in Case V are identical to Case I, except grassland areas not classified as vernal pools are assumed to be a mix of rainfed and perennial grasslands that vary from year to year based on the annual runoff volume as measured by the eight-river index (CDWR, 2013a). Grassland areas are assumed to be perennial in the wettest year, rainfed in the driest year, and for all other years, the mix is assumed to vary linearly with annual runoff volume between the wettest year and the driest year.

Vegetation areas in Case VI are identical to Case I, except vernal pools are assumed to be a mix of rainfed and perennial grassland. Aggregate grasslands are assumed to be perennial in the wettest year, rainfed in the driest year, and for all other years, the mix is assumed to vary linearly with annual runoff volume between the wettest year and the driest year.

We believe Cases V and VI most closely represent water use under natural conditions as it is likely that vegetation varied in this fashion. It is likely that seasonal wetlands varied in a similar fashion, extending further outside of the flood basins in wet years than in dry or critical (Whipple et al., 2012). However, we did not have sufficient data to evaluate this case.

We defined two additional vegetation area cases to explore the uncertainty of natural delta outflow due to evapotranspiration and areal extent of valley foothill hardwoods (Case VII) and wetlands (Case VIII).

Case VII was included to explore the effect of valley/foothill hardwoods composition on natural delta outflow. This case primarily affects Sacramento Basin outflow as $86 \%$ of the hardwood vegetation, or $5300 \mathrm{~km}^{2}$, is in this basin. This vegetation class was subdivided into foothill hardwood, present at higher elevations with deeper water tables, and valley oak savannas, present in the valley floor where water tables were shallow, for purposes of estimating 
evapotranspiration (Howes et al., 2015). Foothill hardwoods likely relied on soil moisture as the water table was generally deeper at these higher elevation areas than on the valley floor. Valley oak savannas, on the other hand, had deep root systems (Howes et al., 2015) that tapped the shallower groundwater at lower elevations (Bertoldi et al., 1991; Bryan, 1915; Kooser et al., 1861).

We had no basis for reliably subdividing valley/foothill hardwood land areas into subclasses. Küchler (1977) suggests that about $65 \%$ was foothill hardwoods. Thus, we evaluated a range. In Case I, we assumed that $100 \%$ of valley/foothill hardwood was foothill hardwood. In Case VII, we assumed $100 \%$ was valley oak savanna, holding all other land areas constant as in Table 3.

Case VIII classifies San Joaquin Basin seasonal wetlands as rainfed grasslands. The San Joaquin Basin was modeled differently based on our annual water balances, as discussed above, supplemented by soil surveys, eyewitness accounts, and the basin's relatively dry hydrology which suggest that rainfed grasslands (rather than seasonal wetland) is a plausible alternate vegetation classification for seasonal wetlands.

\section{Results}

The water balance methodology described previously was used to estimate annual average delta outflow under natural conditions for each year of the 88-year hydrologic sequence (1922-2009). A long-term annual average was computed from individual yearly results and compared with CDWR's $(2007,2012)$ estimates of long-term annual average delta outflow under current conditions and unimpaired conditions for a similar period of record.

The results of our natural delta outflow water balances for eight land use cases are summarized in Table 5 and illustrated in Fig. 5. Under natural conditions, native vegetation used 27.1 to 36.1 billion $\mathrm{m}^{3} \mathrm{yr}^{-1}$ of the natural water supply, falling as precipitation in the mountain ranges surrounding the valley floor and on the valley floor itself. This amounts to 54 to $72 \%$ of the total supply of 50.1 billion $\mathrm{m}^{3} \mathrm{yr}^{-1}$. The water that was not evapotranspired or evaporated, ranging from 14.0 to 23.0 billion $\mathrm{m}^{3} \mathrm{yr}^{-1}$, flowed into the delta and San Francisco Bay. These results are consistent with those reported by others (Shelton, 1987; Bolger et al., 2011; Fox, 1987).

The resulting evapotranspiration-to-precipitation (ET / $P$ ) ratios, 0.54 to 0.72 are estimated as total water use from Table 5 divided by the sum of valley floor precipitation ( 15.9 billion $\mathrm{m}^{3} \mathrm{yr}^{-1}$ ) and rim inflows ( 34.2 billion $^{3} \mathrm{yr}^{-1}$ ), and are consistent with ET / $P$ ratios reported by others (Sanford and Selnick, 2014). The valley floor vegetation described in this work was not sustained by precipitation falling on the valley floor. The valley floor also used large quantities of runoff from surrounding watersheds that was not consumed in those watersheds but was made available for con-

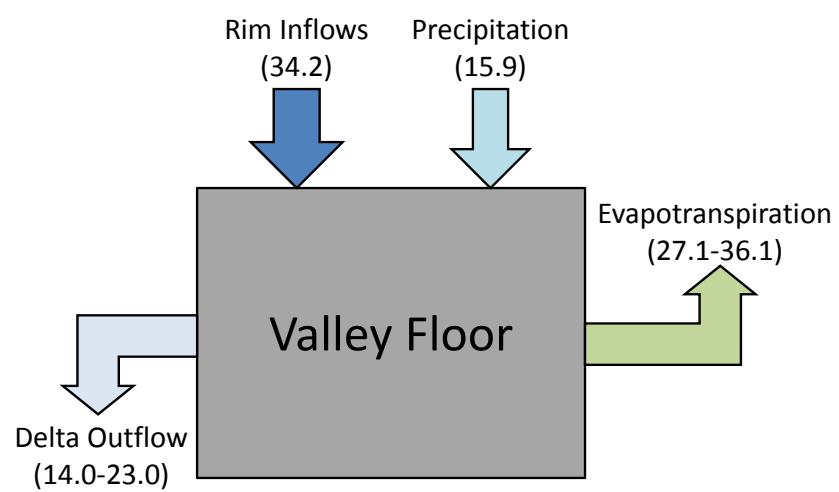

Figure 5. Schematic showing the average (1922-2009) natural water balance results (billion $\mathrm{m}^{3} \mathrm{yr}^{-1}$ ).

sumptive use through the seasonal flooding cycle. Therefore, rim inflows supplement precipitation as a water supply to the valley floor.

In sum, we believe that Cases V and VI, in which the mix of rainfed and perennial grasslands was varied based on the volume of rim inflow to the Sacramento and San Joaquin basins, most closely represent water consumed under natural conditions. In these cases, native vegetation consumed 30.4 to 29.7 billion $\mathrm{m}^{3} \mathrm{yr}^{-1}$ or about $60 \%$ of the natural supply. About $41 \%$ of the native vegetation water use in these two cases was consumed by the grassland-vernal pool complex occupying the area between the foothills and the floodplain. About $34 \%$ of the native vegetation water use was consumed by permanent and seasonal wetlands, largely within the floodplain. The balance of the native vegetation water use was consumed by riparian vegetation $(13 \%)$, foothill hardwoods $(9 \%)$, and saltbush, chaparral, and open water surfaces $(3 \%)$.

In comparison, the current-level, long-term annual average delta outflow is 19.5 billion $\mathrm{m}^{3} \mathrm{yr}^{-1}$ (CDWR, 2012). This estimate was developed using a reservoir system operations model (Draper et al., 2004) and assumes a 2011 level of development for an 82-year hydrologic sequence (1922 to 2003). The current long-term annual average water supply of 51.6 billion $\mathrm{m}^{3} \mathrm{yr}^{-1}$ estimated by CDWR (2012) exceeds the natural water supply in our analysis by 1.5 billion $\mathrm{m}^{3} \mathrm{yr}^{-1}$ due to (1) groundwater overdraft of 0.9 billion $\mathrm{m}^{3} \mathrm{yr}^{-1}$ in the Sacramento and San Joaquin basins and (2) Sacramento River Basin imports of 0.6 billion $\mathrm{m}^{3} \mathrm{yr}^{-1}$ from the US Bureau of Reclamation Trinity River Diversion Project, a project that transfers water from Lewiston Reservoir through the Clear Creek Tunnel to the Sacramento River (CDWR, 2012).

The long-term annual average current-level delta outflow of 19.5 billion $\mathrm{m}^{3} \mathrm{yr}^{-1}$ falls within the range of estimated natural outflows as shown in Fig. 6 for the same period of record (14.0 to 23.0 billion $\mathrm{m}^{3} \mathrm{yr}^{-1}$ ). The current-level water balance indicates that $62 \%$ of the water supply is currently 


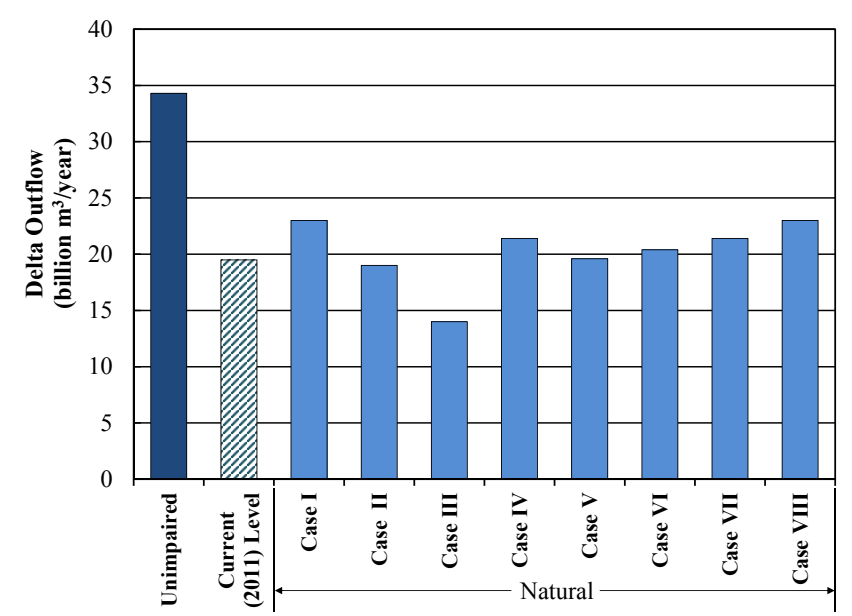

Figure 6. Comparison of long-term (1922-2009) average annual delta outflow estimated based on unimpaired, current (2011) level, and the natural scenarios (Cases I-VII) examined in this study.

consumed by irrigation, municipal, industrial, and other uses, based on the 2011 level of development (CDWR, 2013b). This estimate is roughly the midpoint of the range of estimated natural water use (54 to $72 \%$ ).

Thus, current and natural delta outflows, when reported for the same climatic conditions, are very similar because natural vegetation used nearly as much water (27.1 to 36.1 billion $\mathrm{m}^{3} \mathrm{yr}^{-1}$ ) as is consumed currently (31.9 billion $\mathrm{m}^{3} \mathrm{yr}^{-1}$ ) for agriculture, municipal, industrial, and other uses. Further, the current and natural delta outflow estimates are statistically indistinguishable due to uncertainties described elsewhere.

In sum, reconfiguring the natural water supply to accommodate new land uses (e.g., see Fig. 4), mitigate flooding, and redistribute the water supply in time and space has not substantially changed the annual average amount of freshwater reaching San Francisco Bay from the Central Valley, when controlled for climate. This is the case because natural vegetation consumed about as much water as is currently used by the new land uses within the valley floor as well as outside of it.

We believe our natural delta outflow estimates were based on conservative assumptions that will tend to underestimate evapotranspiration and thus overestimate natural delta outflows. Noteworthy conservative assumptions include (1) all of the permanent wetlands are assumed to be large stand, thereby ignoring higher water-using small stand wetlands and (2) the maps and soil surveys used to estimate natural vegetation underestimate the extent of some types of natural vegetation, such as wetlands and vernal pools, because significant modifications had been made to the landscape prior to the date of its earliest source (1874).

\section{Discussion}

This study shows that long-term annual average current and natural outflows fall within the same range, when controlled for climatic conditions. This occurs as the amount of water currently used from valley floor watersheds for agriculture, domestic, industrial, and other uses is about equal to the amount of water that would be used if the existing engineered system were replaced by natural vegetation.

An estimate of natural delta outflows is important as reduction in the volume of freshwater reaching the San Francisco Bay-Delta estuary due to the current level of development has frequently been advanced as one of the causes for the decline in abundance of native species. Further, estimates of hypothetical natural outflow (so-called unimpaired outflows) have been proposed to regulate current delta outflows in an effort to restore ecological health of the estuary. This work indicates that restoring flows to annual average natural outflows are unlikely to restore ecosystem health because they are indistinguishable from annual average current outflows.

The reduced outflow hypothesis advanced by some as a cause of declines in native fish abundance is typically based on unimpaired flows of 34.3 billion $\mathrm{m}^{3} \mathrm{yr}^{-1}$ published by CDWR (2007). These unimpaired flows are hypothetical flows that never existed. CDWR (2007) differentiates unimpaired delta outflow from natural delta outflow by characterizing them as "runoff that would have occurred had water flow remained unaltered in rivers and streams instead of stored in reservoir, imported, exported, or diverted. The data are a measure of the total water supply available for all uses after removing the impacts of most upstream alterations as they occurred over the years. Alterations such as channel improvements, levees, and flood bypasses are assumed to exist."

The long-term annual average unimpaired delta outflow estimate of 34.3 billion $\mathrm{m}^{3} \mathrm{yr}^{-1}$ assumes the same rim inflows and valley floor precipitation used in our natural water balances in Table 5. However, rather than reducing water supply to account for water use associated with the full extent of natural vegetation in the valley floor, the unimpaired outflow calculation assumes that water use upstream of the delta is limited to only valley floor precipitation (CDWR, 2007). In other words, the unimpaired outflow calculation assumes the only vegetation present outside of the delta was perennial grasslands with no access to groundwater. It ignores the presence of perennial grasslands, vernal pools, wetlands, riparian forest, and valley oak savannahs.

Thus, the unimpaired outflow calculation effectively assumes rim inflows pass through the valley floor and arrive in the delta in the current system of channel improvements, levees, and flood bypasses (i.e., the difference between the natural water supply of 50.1 billion $\mathrm{m}^{3} \mathrm{yr}^{-1}$ and valley floor precipitation of 15.9 billion $\mathrm{m}^{3} \mathrm{yr}^{-1}$ is 34.2 billion $\mathrm{m}^{3} \mathrm{yr}^{-1}$ ). Thus, by definition, unimpaired delta outflow calculations provide a high estimate when used as a surrogate for natural delta outflow. 
Table 5. Natural water balance 1922-2009 valley floor (billion $\mathrm{m}^{3} \mathrm{yr}^{-1}$ ).

\begin{tabular}{|c|c|c|c|c|c|c|c|c|c|}
\hline \multicolumn{2}{|c|}{ Water supply } & \multicolumn{8}{|c|}{ Water use (billion $\mathrm{m}^{3} \mathrm{yr}^{-1}$ ) } \\
\hline $\begin{array}{l}\text { Inflow } \\
\text { Precipitation }\end{array}$ & $\begin{array}{l}34.2 \\
15.9\end{array}$ & \multicolumn{4}{|c|}{$\begin{array}{l}\text { Grasslands - } \\
\text { constant area }\end{array}$} & \multicolumn{2}{|c|}{$\begin{array}{l}\text { Grasslands - } \\
\text { variable area }\end{array}$} & \multicolumn{2}{|c|}{$\begin{array}{c}\text { Other } \\
\text { vegetation }\end{array}$} \\
\hline Total water supply & 50.1 & Case I & Case II & Case III & Case IV & Case V & Case VI & Case VII & Case VIII \\
\hline \multicolumn{10}{|c|}{ Sacramento Basin } \\
\hline Rainfed grasslands & & 1.5 & 0.0 & 0.0 & 0.0 & 0.9 & 1.5 & 1.5 & 0.0 \\
\hline Perennial grasslands & & 0.0 & 0.0 & 5.6 & 5.6 & 2.1 & 3.6 & 0.0 & 5.6 \\
\hline Vernal pool & & 2.2 & 5.4 & 2.2 & 2.2 & 2.2 & 0.0 & 2.2 & 2.2 \\
\hline Large stand wetland & & 2.3 & 2.3 & 2.3 & 2.3 & 2.3 & 2.3 & 2.3 & 2.3 \\
\hline Seasonal wetland & & 2.2 & 2.2 & 2.2 & 2.2 & 2.2 & 2.2 & 2.2 & 2.2 \\
\hline Foothill hardwood & & 2.3 & 2.3 & 2.3 & 2.3 & 2.3 & 2.3 & 0.0 & 2.3 \\
\hline Valley oak savanna & & 0.0 & 0.0 & 0.0 & 0.0 & 0.0 & 0.0 & 3.7 & 0.0 \\
\hline Riparian forest & & 3.3 & 3.3 & 3.3 & 3.3 & 3.3 & 3.3 & 3.3 & 3.3 \\
\hline Saltbush & & 0.0 & 0.0 & 0.0 & 0.0 & 0.0 & 0.0 & 0.0 & 0.0 \\
\hline Chaparral & & 0.1 & 0.1 & 0.1 & 0.1 & 0.1 & 0.1 & 0.1 & 0.1 \\
\hline \multirow[t]{2}{*}{ Aquatic surface } & & 0.1 & 0.1 & 0.1 & 0.1 & 0.1 & 0.1 & 0.1 & 0.1 \\
\hline & & 14.2 & 15.9 & 18.2 & 18.2 & 15.7 & 15.5 & 15.5 & 18.2 \\
\hline \multicolumn{10}{|c|}{ Delta } \\
\hline Rainfed grassland & & 0.1 & 0.0 & 0.0 & 0.0 & 0.0 & 0.1 & 0.1 & 0.0 \\
\hline Perennial grassland & & 0.0 & 0.0 & 0.4 & 0.4 & 0.1 & 0.1 & 0.0 & 0.4 \\
\hline Vernal pool & & 0.1 & 0.3 & 0.1 & 0.1 & 0.1 & 0.0 & 0.1 & 0.1 \\
\hline Large stand wetland & & 2.8 & 2.8 & 2.8 & 2.8 & 2.8 & 2.8 & 2.8 & 2.8 \\
\hline Seasonal wetland & & 0.3 & 0.3 & 0.3 & 0.3 & 0.3 & 0.3 & 0.3 & 0.3 \\
\hline Foothill hardwood & & 0.0 & 0.0 & 0.0 & 0.0 & 0.0 & 0.0 & 0.0 & 0.0 \\
\hline Valley oak savanna & & 0.0 & 0.0 & 0.0 & 0.0 & 0.0 & 0.0 & 0.0 & 0.0 \\
\hline Riparian forest & & 0.0 & 0.0 & 0.0 & 0.0 & 0.0 & 0.0 & 0.0 & 0.0 \\
\hline Saltbush & & 0.0 & 0.0 & 0.0 & 0.0 & 0.0 & 0.0 & 0.0 & 0.0 \\
\hline Chaparral & & 0.0 & 0.0 & 0.0 & 0.0 & 0.0 & 0.0 & 0.0 & 0.0 \\
\hline \multirow[t]{2}{*}{ Aquatic surface } & & 0.1 & 0.1 & 0.1 & 0.1 & 0.1 & 0.1 & 0.1 & 0.1 \\
\hline & & 3.5 & 3.5 & 3.7 & 3.7 & 3.5 & 3.5 & 3.5 & 3.7 \\
\hline \multicolumn{10}{|c|}{ San Joaquin Basin } \\
\hline Rainfed grasslands & & 1.1 & 0.0 & 0.0 & 2.6 & 0.7 & 1.5 & 1.1 & 3.0 \\
\hline Perennial grasslands & & 0.0 & 0.0 & 5.8 & 0.0 & 2.2 & 5.1 & 0.0 & 0.0 \\
\hline Vernal pools & & 4.2 & 7.5 & 4.2 & 0.0 & 4.2 & 0.0 & 4.2 & 0.0 \\
\hline Large stand wetlands & & 0.6 & 0.6 & 0.6 & 0.6 & 0.6 & 0.6 & 0.6 & 0.6 \\
\hline Seasonal wetland & & 2.0 & 2.0 & 2.0 & 2.0 & 2.0 & 2.0 & 2.0 & 0.0 \\
\hline Foothill hardwoods & & 0.4 & 0.4 & 0.4 & 0.4 & 0.4 & 0.4 & 0.0 & 0.4 \\
\hline Valley oak savanna & & 0.0 & 0.0 & 0.0 & 0.0 & 0.0 & 0.0 & 0.6 & 0.0 \\
\hline Riparian forest & & 0.7 & 0.7 & 0.7 & 0.7 & 0.7 & 0.7 & 0.7 & 0.7 \\
\hline Saltbush & & 0.4 & 0.4 & 0.4 & 0.4 & 0.4 & 0.4 & 0.4 & 0.4 \\
\hline Chaparral & & 0.0 & 0.0 & 0.0 & 0.0 & 0.0 & 0.0 & 0.0 & 0.0 \\
\hline \multirow{2}{*}{\multicolumn{2}{|c|}{ Aquatic surface }} & 0.1 & 0.1 & 0.1 & 0.1 & 0.1 & 0.1 & 0.1 & 0.1 \\
\hline & & 9.5 & 11.7 & 14.2 & 6.8 & 11.3 & 10.7 & 9.7 & 5.2 \\
\hline Total water use & & 27.1 & 31.1 & 36.1 & 28.7 & 30.4 & 29.7 & 28.7 & 27.1 \\
\hline $\begin{array}{l}\text { delta outflow }=\text { total } \\
- \text { total water use }\end{array}$ & er supply & 23.0 & 19.0 & 14.0 & 21.4 & 19.6 & 20.4 & 21.4 & 23.0 \\
\hline
\end{tabular}


In spite of CDWR's caveats of its theoretical calculation of unimpaired delta outflow from natural delta outflow, unimpaired outflows have frequently been used as a surrogate measure of natural conditions, presumably because no estimate of natural delta outflow was published prior to this work. For example, Dynesius and Nilsson (1994) argue that the bay-delta watershed is strongly affected by fragmentation due to the difference between current delta outflow and the delta's reported virgin mean annual discharge of 34.8 billion $\mathrm{m}^{3} \mathrm{yr}^{-1}$, a quantity roughly equivalent to CDWR's long-term annual average unimpaired delta outflow calculation published by CDWR at the time of this work. More recently, the California State Water Resources Control Board (CSWRCB, 2010) submitted a report to the state legislature suggesting a flow criterion of $75 \%$ of unimpaired delta outflow from January through June "in order to preserve the attributes of the natural variable system to which native fish species are adapted." This suggested criterion was based on fishery protection alone and did not consider other beneficial uses of water in the estuary.

Native aquatic species evolved under natural landscape conditions. Figure 4 demonstrates that very little of the natural landscape remains. Thus, habitat restoration may be an important ingredient in restoring these species. Understanding natural delta outflow and how it interacts with the natural landscape will be important to guide future restoration planning activities. The Comprehensive Everglades Restoration Plan (CERP), for example, used natural system modeling to gain a better understanding of south Florida's hydrology prior to drainage and development. CERP, which was designed to restore the Everglades ecosystem while maintaining adequate flood protection and water supply for south Florida, is using insights gained by this modeling effort, in combination with other adaptive management tools, to formulate restoration plans and set targets (SFWMD, 2014).

California's Bay Delta Conservation Plan, another such planning activity, envisions a reversal of the delta's ecosystem decline through protection and creation of approximately $590 \mathrm{~km}^{2}$ of aquatic and terrestrial habitat (CDWR and USBR, 2013). By reconnecting floodplains, developing new marshes, and returning riverbanks to a more natural state, the plan is designed to boost food supplies and provide greater protection for native fisheries.

\section{Conclusions and recommendations}

This study found that the amount of water from the valley floor watershed currently consumed for agriculture, domestic, industrial, and other uses is roughly equal to the amount of water formerly used by native vegetation in this same watershed. Thus, delta outflow, or the amount of freshwater reaching San Francisco Bay, is about the same under current conditions as under natural conditions, when controlled for climate.
This finding, which used a conventional water balance methodology and assumed contemporary climatic conditions for both natural and current landscapes, suggests that human disturbances to the landscape and hydrologic cycle have not significantly reduced the annual average volume of freshwater flows entering San Francisco Bay through the delta. Rather, development has simply redistributed flows from natural vegetation to other beneficial uses. Thus, it is unlikely that observed declines in native freshwater aquatic species are due to reduction in annual average delta outflow.

Another key finding of this study is that unimpaired delta outflow calculations significantly overestimate natural delta outflow as they fail to include consumptive use by natural vegetation in the valley floor other than rainfed grasslands. Therefore, unimpaired delta outflow calculations should not be used as a surrogate measure of natural conditions or to set flow standards to restore ecosystem health.

Several limitations associated with this work point to areas for future research. The simple water balance methodology utilized in this paper is an appropriate reconnaissance-level step in reconstructing the natural hydrology of a complex system. However, this simple approach is unable to explore several important and relevant questions.

First, our analysis only considers long-term annual averages and does not evaluate inter- and intra-annual variability of natural delta outflow. Ecosystems respond to flows at timescales much shorter than annual. Thus, future work should consider these shorter timescales.

Second, our analysis does not account for complex interactions between groundwater and surface water. These interactions would place important limits on water availability to vegetation in a natural landscape on a shorter timescale.

Third, many vegetation land areas likely varied with the wetness of the year. We attempted to address this using a sensitivity analysis in which grassland-vernal pool areas were varied as a function of rim inflows and other assumptions.

Finally, we assumed natural evapotranspiration rates for vegetation types with a continuous water supply, e.g., permanent wetlands, are constant over the period of record. They likely varied as a function of climate. Future work should include a sensitivity analysis of vegetation coefficient ranges such as those shown in Howes et al. (2015).

We recommend future research in several areas of historical landscape ecology, hydrology, and estuarine hydrodynamics to address these limitations to support ongoing regulatory and habitat restoration activities in the San Francisco Bay-Delta watershed, including

- refined natural vegetation mapping in the Sacramento and San Joaquin basins, following work in the delta reported by Whipple et al. (2012);

- evapotranspiration from vernal pools and seasonal wetlands; 
- interactions between groundwater and surface water under natural conditions;

- inter- and intra-annual variability of natural delta outflows;

- natural watershed geomorphology;

- natural estuarine salinity transport.

We recommend that integrated groundwater-surface water models, digital elevation models and hydrodynamic models be developed to support this research. Several collaborative efforts are currently underway to develop such models (Draper, 2014; Kadir and Huang, 2014; Grossinger et al., 2014; Fleenor et al., 2014; DeGeorge and Andrews, 2014). Finally, we recommend future research be conducted to compare the evolution of the San Francisco Bay-Delta watershed with other watersheds around the world.

Acknowledgements. This work was partially funded by San Luis Delta Mendota Water Authority and the State Water Contractors and voluntary contributions of the authors. This work benefited greatly from discussion with and information provided by Robert F. Holland (unpublished vernal pool GIS shape files), as well as Rusty Griffin, US Fish \& Wildlife Service (historic wetlands map). The model used for sensitivity analysis and case definition was developed by Louis Nuyens, Peter Louie (Metropolitan Water District), and Gomathishankar (Shankar) Parvathinathan (MWH).

Edited by: M. Sivapalan

\section{References}

Alexander, B. S., Mendell, G. H., and Davidson, G.: Report of the Board of Commissioners on the Irrigation of the San Joaquin, Tulare, and Sacramento Valleys of the State of California, 43rd Congress, 1st Session, House of Representation, Ex. Doc. No. 290, Government Printing Office, Washington, 1874.

Allen, R. G., Pereira, L. S., Raes, D., and Smith, M.: Crop Evapotranspiration: guidelines for computing crop water requirements, FAO Irrigation and Drainage Paper No. 56, Food and Agricultural Organization of the United Nations, Rome, Italy, 1998.

Allen, R. G., Walter, I. A., Elliott, R. L., Howell, T. A., Itenfisu, D., Jensen, M. E., and Snyder, R. L. (Eds.): The ASCE Standardized Reference Evapotranspiration Equation, ASCE, Reston, Virginia, 2005.

Anonymous: Commissioners and Surveyor-General's Instructions to the County Surveyors of California, California State Printing Office, Sacramento, CA, USA, 1861.

Armstrong, C. F. and Stidd, C. K.: A moisture-balance profile on the Sierra Nevada, J. Hydrol., 5, 258-268, 1967.

Bain, J. S., Caves, R. E., and Margolis, J.: Northern California's Water Industry: The Comparative Efficiency of Public Enterprise in Developing a Scarce Natural Resource, Published for Resources for the Future, Inc., The Johns Hopkins Press, Baltimore, MD, 1966.
Bales, R. C., Battles, J. J., Chen, Y., Conklin, M. H., Holst, E., O'Hara, K. L., Saksa, P., and Stewart, W.: Forests and Water in the Sierra Nevada: Sierra Nevada Watershed Ecosystem Enhancement Project, report number 11.1, Sierra Nevada Research Institute, 2011.

Barbour, M. G., Pavlik, B., Drysdale, F., and Lindstrom, S.: California's changing landscapes, Diversity and Conservation of California Vegetation, California Native Plant Society, Sacramento, CA, 1993.

Bartolome, J. W., Barry, W. J., Griggs, T., and Hopkinson, P.: Valley grasslands, in: Chapter 14, Terrestrial Vegetation of California, edited by: Barbour, M. G., Keeler-Wolf, T., and Schoenheer, A. A., University of California Press, Berkeley, 367-393, 2007.

Bennett, W. A. and Moyle, P. B.: Where have all the fishes gone? Interactive factors producing fish declines in the Sacramento-San Joaquin estuary, in: San Francisco Bay: The Ecosystem, edited by: Hollibaugh, J. T., Pacific Division of the American Association for the Advancement of Science, San Francisco, CA, 519542, 1996.

Bertoldi, G. L., Johnston, R. J., and Evenson, K. D.: Ground Water in the Central Valley, California - A Summary Report, US Geological Survey Professional Paper 1401-A, United States Government Printing Office, Washington, D.C., USA, 1991.

Bolger, B. L., Park, Y.-J., Unger, A. J. A., and Sudicky, E. A.: Simulating the pre-development hydrologic conditions in the San Joaquin Valley, California, J. Hydrol., 411, 322-330, 2011.

Bryan, K.: Groundwater for Irrigation in the Sacramento Valley, California, US Geological Survey Water-Supply Paper 375-A, United States Government Printing Office, Washington, D.C., USA, 1915.

Bryan, K.: Geology and Ground-Water Resources of the Sacramento Valley, California, US Geological Survey Water-Supply Paper 495, United States Government Printing Office, Washington, D.C., USA, 1923.

Burcham, L. T.: California Range Land: An Historical-Ecological Study of the Range Resource of California, CA, Department of Natural Resources, Division of Forestry, Sacramento, CA, 1957.

California State Engineer: Report of the State Engineer of the State of California, Sacramento, CA, USA, 11 May 1907 to 30 November 1908 .

CDPW - California Department of Public Works: Sacramento River Basin, Bulletin No. 26, Sacramento, CA, USA, 1931a.

CDPW - California Department of Public Works: San Joaquin River Basin, Bulletin No. 29, Sacramento, CA, USA, 1931 b.

CDWR - California Department of Water Resources: California Planning Areas, Prepared by Scott Hayes, 31 October 2005, available at: http://www.waterplan.water.ca.gov/docs/ maps/pa-web.pdf (last access: 15 January 2015), 2005a.

CDWR - California Department of Water Resources: California Detailed Analysis Units, Prepared by Scott Hayes, 31 October 2005, available at: http://www.waterplan.water.ca.gov/docs/ maps/dau-web.pdf (last access: 15 January 2015), 2005b.

CDWR - California Department of Water Resources: California Central Valley Unimpaired Flow Data, 4th Edn., Draft, BayDelta Office, California Department of Water Resources, Sacramento, CA, May 2007.

CDWR - California Department of Water Resources: The State Water Project Final Delivery Reliability Report 2011, available 
at: http://baydeltaoffice.water.ca.gov/swpreliability/FINAL_ 2011_DRR.pdf (last access: 1 March 2015), 2012.

CDWR - California Department of Water Resources: California Data Exchange Center, Chronological Reconstructed Sacramento and San Joaquin Valley Water Year Hydrologic Classification Indices, available at: http://cdec.water.ca.gov/cgi-progs/ iodir/WSIHIST (last access: 8 April 2015), 2013a.

CDWR - California Department of Water Resources: California Water Plan, Update 2013, Bulletin 160-13, Sacramento, CA, USA, 2013b.

CDWR and USBR - California Department of Water Resources and US Department of the Interior, Bureau of Reclamation: Bay Delta Conservation Plan, Public Draft, November 2013, available at: http://baydeltaconservationplan.com (last access: 3 February 2015), 2013.

Cloern, J. E. and Jassby, A. D.: Drivers of change in estuarinecoastal ecosystems: discoveries from four decades of study in San Francisco Bay, Rev. Geophys., 50, 1-33, 2012.

CSG - California Surveyor-General: Annual Report of the Surveyor-General of the State of California. Document No. 5, in: Senate, Session of 1856, Sacramento, available at: http://www. slc.ca.gov/Reports/Surveyors_General/reports/Marlette1855.pdf (last access: 7 April 2015), 1856.

CSG - California Surveyor-General: Annual Report of the Surveyor-General of California for the Year 1862, Sacramento, available at: http://www.slc.ca.gov/Reports/surveyors_general/ reports/houghton1862.pdf (last access: 7 April 2015), 1862.

CSU Chico - California State University: The Central Valley Historic Mapping Project, Chico, CA, USA, April 2003.

CSWRCB - California State Water Resources Control Board: Development of Flow Criteria for the Sacramento-San Joaquin Delta Ecosystem, Prepared Pursuant to the Sacramento-San Joaquin Delta Reform Act of 2009, Sacramento, CA, USA, August 2010 .

Cunningham, L.: A State of Change: Forgotten Landscapes of California, Heyday, Berkeley, CA, 2010.

Daly, C. and Bryant, K.: The PRISM climate and weather system - an introduction, PRISM Climate Group, Northwest Alliance for Computational Science and Engineering, Oregon State University, Corvallis, OR, USA, available at: http://www.prism. oregonstate.edu/documents/PRISM_historyjun2013.pdf (last access: 7 April 2015), 2013.

Daly, C., Taylor, G. H., Gibson, W. P., Parzybok, T. W., Johnson, G. L., and Pasteris, P. A.: High-quality spatial climate data sets for the United States and beyond, Trans. ASAE, 6, 1957-1962, 2000.

Davis, G. H., Green, J. H., Olmsted, F. H., and Brown, D. W.: Ground-water conditions and storage capacity in the San Joaquin Valley, California, US Geological Survey Water Supply Paper 1469, United States Government Printing Office, Washington, D.C., USA, 1959.

DeGeorge, J. and Andrews, S.: Natural Delta Hydrodynamic Model Development, Presented at the 8th Biennial Bay-Delta Science Conference, 28-30 October, Sacramento, CA, p. 38, available at: http://scienceconf2014.deltacouncil.ca.gov/sites/default/files/ uploads/OralAbstractsFull.pdf (last access: 7 April 2015), 2014.

Draper, A. J.: Natural flow monthly routing model, Presented at the California Water and Environmental Modeling Forum Annual Meeting, 24-26 February, Folsom, CA, p. 36, avail- able at: http://www.cwemf.org/AnnualMeeting/2014Abstracts. pdf (last access: 7 April 2015), 2014.

Draper, A. J., Munevar, A., Arora, S. K., Reyes, E., Parker, N. L., Chung, F. I., and Peterson, L. E.: CalSim: generalized model for reservoir system analysis, J. Water Res. Pl. ASCE, 6, 480-489, 2004.

Dutzi, E. J.: Valley Oaks in the Sacramento Valley: Past and Present Distribution, Master of Arts Thesis in Geography, University of California, Davis, 1978.

Dynesius, M. and Nilsson, C.: Fragmentation and flow regulation of river systems in the northern third of the world, Science, 266, 753-762, 1994.

Fleenor, W., Whipple, A., Bell, A., Lay, M., Grossinger, R., Safran, S., and Beagle, J.: Generating a historical Delta bathymetrictopographical digital elevation model (Part II) Data Interpolation, 24-26 February, Folsom, CA, p. 39, available at: http: //www.cwemf.org/ (last access: 7 April 2015), 2014.

Flushman, B. S.: Water Boundaries: Demystifying Land Boundaries Adjacent to Tidal or Navigable Waters, John Wiley \& Sons, Inc. New York, NY, USA, 2002.

Fox, J. P.: Freshwater Inflow to San Francisco Bay Under Natural Conditions, Appendix 2, SWC Exhibit No. 262, Calif. State Water Resources Hearings on the Bay-Delta, December 1987, Sacramento, CA, USA, 1987.

Fox, J. P. and Sears, L.: Natural Vegetation in the Central Valley of California, Project Report Prepared for San Luis Delta Mendota Water Authority and the State Water Contractors, San Luis Delta Mendota Water Authority and State Water Contractors, Sacramento, CA, USA, 2014.

Frayer, W. E., Peters, D. D., and Pywell, H. R.: Wetlands of the California Central Valley, Status and Trends - 1939 to mid-1980s, US Fish and Wildlife Service Report, US Fish and Wildlife Service, Region 1, Portland, OR, USA, June 1989.

Garone, P.: The Fall and Rise of the Wetlands of California's Great Central Valley, University of California Press, Berkeley, 2011.

Gleick, P. H.: The development and testing of a water balance model for climate impact assessment: modeling the Sacramento Basin, Water Resour. Res., 6, 1049-1061, 1987.

Glibert, P. M.: Long-term changes in nutrient loading and stoichiometry and their relationships with changes in the food web and dominant Pelagic fish species in the San Francisco Estuary,California, Rev. Fish. Sci., 18, 211-232, 2010.

Glibert, P. M., Fullerton, D., Burkholder, J. M., Cornwell, J. C., and Kana, T. M.: Ecological stoichiometry, biogeochemical cycling, invasive species, and aquatic food webs: San Francisco estuary and comparative systems, Rev. Fish. Sci., 4, 358-417, 2011.

Grossinger, R., Safran, S., Beagle, J., DeGeorge, J., Fleenor, W., Whipple, A., Bell, A., and Lay, M.: Generating a historical Delta bathymetric-topographical digital elevation model (Part I) data collection and development, Presented at the California Water and Environmental Modeling Forum Annual Meeting, 2426 February, Folsom, CA, available at: http://www.cwemf.org/ AnnualMeeting/2014Abstracts.pdf (last access: 7 April 2015), 2014.

Grunsky, C. E.: The relief outlets and by-passes of the Sacramento Valley flood-control project, Trans. ASCE, 93, 791-811, 1929.

Hall, W. H.: Report of the State Engineer to the Legislature of California, Session of 1880, Part 2, California State Printer, Sacramento, CA, USA, 1880. 
Hall, W. H.: Topographical and Irrigation Map of the Great Central Valley of California Embracing the Sacramento, San Joaquin, Tulare and Kern Valleys and the Bordering Foothills, California State Engineering Department, Sacramento, CA, USA, 1887.

Heady, H. E., Bartolome, J. W., and Pitt, M. D.: California prairie, in: Natural Grasslands, edited by: Copland, R. T., Elsevier, New York, 313-332, 1992.

Heady, H. F.: Valley grasslands, in: Chapter 14, Terrestrial Vegetation of California, edited by: Barbour, M. G. and Major, J., John Wiley \& Sons Inc., New York, NY, USA, 491-513, 1988.

Hilgard, E. W.: Report on the Physical and Agricultural Features of the State of California, Vol. 6, Tenth Census, US Census Office, Government Printing Office, Washington, D.C., 649-796, 1884.

Holland, R. F.: The Geographic and Edaphic Distribution of Vernal Pools in the Great Central Valley, California, California Native Plant Society Special Publications No. 4, California Native Plant Society, Fair Oaks, CA, USA, 1978.

Holland, R. F.: Changes in Great Valley Vernal Pool Distribution from 1989 to 1997, available at: http: //www.dfg.ca.gov/biogeodata/wetlands/pdfs/Holland_ ChangesInGreatValleyVernalPoolDistribution.pdf last access: 9 April 2015, California Department of Fish and Game, Sacramento, CA, 1998.

Holland, R. F.: GIS shape files for Holland vernal pool map, email from Holland, R. to Sears, L., 4 December 2013.

Holland, R. F. and Hollander, A. D.: Hogwallow biogeography before gracias, in: Vernal Pool Landscapes, Studies from the Herbarium, Number 14, edited by: Schlising, R. A. and Alexander, D. G., California State University, Chico, 2007.

Holmes, L. C. and Eckmann, E. C.: Soil Survey of the Red Bluff Area, California, US Department of Agriculture, Bureau of Soils, Washington, D.C., 1912.

Holmes, L. C., Nelson, J. W., and Party: Reconnaissance Soil Survey of the Sacramento Valley, California, US Department of Agriculture, Bureau of Soils, Washington, D.C., 1915.

Holmes, T. H. and Rice, K. J.: Patterns of growth and soil-water utilization in some exotic annuals and native perennial bunchgrasses of California, Ann. Bot., 78, 233-243, 1996.

Holstein, G.: Pre-agricultural grassland in Central California, Madroño, 4, 253-264, 2001.

Howes, D. J. and Pasquet, M.: Grass reference based vegetation coefficients for estimating evapotranspiration for a variety of natural vegetation, US Committee on Irrigation and Drainage, Proc. of October 2013 Conference, 22-25 October, Denver, CO, 181-194, 2013.

Howes, D. J., Fox, J. P., and Hutton, P.: Evapotranspiration from Natural Vegetation in the Central Valley of California: Monthly Grass Reference-Based Vegetation Coefficients and the Dual Crop Coefficient Approach, J. Hydrol. Eng., 20, 04015004, doi:10.1061/(ASCE)HE.1943-5584.0001162, 2015

Hundley Jr., N.: The Great Thirst, University of California Press, Berkeley, 2001

Ingram, B. L., Conrad, M. E., and Ingle, J. C.: Stable isotope record of late Holocene salinity and river discharge in San Francisco Bay, California, Earth Planet. Sc. Lett., 141, 237-247, 1996.

Jassby, A. D., Kimmerer, W. J., Monismith, S. G., Armor, C., Cloern, J. E., Powell, T. M., Schubel, J. R., and Vendlinski, T. J.: Isohaline position as a habitat indicator for estuary populations, Ecol. Appl., 1, 272-289, 1995.
Kadir, K. and Huang, G.: Simulated 1922-2009 daily inflows to the Sacramento-San Joaquin Delta under predevelopment conditions using precipitation-runoff models and C2VSIM: preliminary results, Presented at the California Water and Environmental Modeling Forum Annual Meeting, 24-26 February, Folsom, CA, p. 38, available at: http://www.cwemf.org/AnnualMeeting/ 2014Abstracts.pdf (last access: 7 April 2015), 2014.

Kahrl, W. L.: The California Water Atlas, State of California, Prepared by the Governor's Office of Planning and Research in Cooperation with the CA DWR, Sacramento, CA, USA, 1979.

Katibah, E. F.: A brief history of riparian forests in the Central Valley of California, in: California Riparian Forests, edited by: Warner, R. E. and Hendrix, K. M., University of California Press, Berkeley, 23-29, 1984.

Kelley, R. L.: Gold vs. grain: The hydraulic mining controversy in California's Sacramento Valley: a chapter in the decline of the concept of laissez faire, Arthur H. Clark Company, Glendale, CA, USA, 327 pp., 1959.

Kelley, R. L.: Battling the Inland Sea: Flood, Public Policy and the Sacramento Valley, University of California Press, Berkeley, CA, 1989.

Kooser, B. P., Seabough, S., and Sargent, F. L.: Notes of trips of the San Joaquin Valley Agricultural Society's visiting committee on orchards and vineyards, Reports of Committees, Committees Nos. 1 and 2 on Farms and Orchards, Trans. S. J. V. Agr. Soc., Sacramento, 258-298, 1861 .

Küchler, A. W.: Natural vegetation of California, pocket map, in: Terrestrial Vegetation of California, edited by: Barbour, M. G. and Major, J., John Wiley \& Sons, Inc., New York, NY, USA, 909-938, 1977.

Lapham, M. H. and Holmes, L. C.: Soil Survey of the Redding Area, California, US Department of Agriculture, Bureau of Soils, Washington, D.C., 1908.

Lapham, M. H., Root, A. S., and Mackie, W. W.: Soil Survey of the Sacramento Area, California, US Department of Agricultural Field Operations Bureau of Soils, United States Government Printing Office, Washington, D.C., USA, 1904.

Lapham, M. H., Sweet, A. T., Strahorn, A. T., and Holmes, L. C.: Soil Survey of the Colusa Area, California, US Department of Agriculture, Bureau of Soils, US Department of Agricultural Field Operations Bureau of Soils, United States Government Printing Office, Washington, D.C., USA, 1909.

Lund, J., Hanak, E., Fleenor, W., Howitt, R., Mount, J., and Moyle, P.: Envisioning Futures for the Sacramento-San Joaquin Delta, Public Policy Institute of California, San Francisco, CA, 2007.

Luoma, S. N. and Nichols, F. H.: Challenges in detecting contaminant effects on an estuarine ecosystem affected by many different disturbances: San Francisco Bay, Water-Resources Investigations Report 94-4015, US Geological Survey Toxic Substances Hydrology Program, Proc. Tech. Mtng., 20-24 September 1993, Colorado Springs, Colorado, 1993.

MacNally, R., Thomson, J. R., Kimmerer, W. J., Feyrer, F., Newman, K. B., Sih, A., Bennett, W. A., Brown, L., Fleishman, E., Culberson, S. D., and Castillo, G.: Analysis of pelagic species decline in the upper San Francisco Estuary using multivariate autoregressive modeling (MAR), Ecol. Appl., 20, 1417-1430, 2010.

Malamud-Roam, F. P., Ingram, B. L., Hughes, M., and Florsheim, J. L.: Holocen paleoclimate records from a large California estu- 
arine system and its watershed region: linking watershed climate and bay conditions, Quarternary Sci. Rev., 13-14, 1570-1598, 2006.

Mann, C. W., Warner, J. F., Westover, H. L., and Ferguson, J. E.: Soil Survey of the Woodland Area, California, US Department of Agriculture, Bureau of Soils, Washington, D.C., 1911.

Meko, D. M., Therrell, M. D., Baisan, C. H., and Hughes, M. K.: Sacramento River flow reconstructed to A.D. 869 from tree rings, J. Am. Water Res. As., 4, 1029-1038, 2001.

Miller, W. J., Bryan, F. J., Manly, D., Murphy, D., Fullerton, D., and Ramey, R. R.: An investigation of factors affecting the decline of Delta Smelt (Hypomesus transpacificus) in the Sacramento-San Joaquin Estuary, Rev. Fish. Sci., 1, 1-19, 2012.

Nelson, J. W., Guernsey, J. E., Holmes, L. C., and Eckmann, E. C.: Reconnaissance Soil Survey of the Lower San Joaquin Valley, California, US Department of Agriculture, Bureau of Soils, Washington, D.C., 1918.

Olmstead, A. L. and Rhode, P. W.: The evolution of California agriculture 1850-2000, in: California Agriculture: Dimensions and Issues, edited by: Siebert, J. B., University of California Press, available at: http://giannini.ucop.edu/CalAgBook/Chap1. pdf (last access: 8 April 2015), 2004.

PRISM Climate Group: Descriptions of PRISM Spatial Climate Datasets for the Conterminous United States, available at: http://www.prism.oregonstate.edu/documents/PRISM_ datasetsaug2013.pdf (last access: 9 April 2015), 2013.

Roberts, W. G., Howe, J. G., and Major, J.: A survey of riparian forest flora and fauna in California, in: Riparian Forests in California: their Ecology and Conservation, Publication No. 15, edited by: Sands, A., A Symposium Sponsored by Institute of Ecology, University of California, Davis and Davis Audubon Society Institute of Ecology, Davis, 14 May 1977.

Sanford, W. E. and Selnick, D. L.: Estimation of evapotranspiration across the conterminous United States using a regression with climate and land cover data, J. Am. Water Resour. Assoc., 49, 217-230, 2014.

Schiffman, P. M.: Species composition at the time of first European settlement, in: California Grasslands: Ecology and Management, edited by: Stromberg, M. R., Corbin, J. D., and D'Antonio, C. M., University of California Press, Berkeley, 52-56, 2007.

SFWMD - South Florida Water Management District: Natural System Regional Simulation Model (NSRSM) Fact Sheet, available at: http://sfwmd.gov, last access: 5 February 2015, West Palm Beach, Florida, USA, 2014.

Shelton, M. L.: Irrigation induced change in fegetation and evapotranspiration in the Central Valley of California, Landscape Ecol., 2, 95-105, 1987.

Smith, D. W. and Verrill, W. L.: Vernal pool-soil-landform relationships in the Central Valley, California, in: Ecology, Conservation, and Management of Vernal Pool Ecosystems, edited by: Witham, C. W., Bauder, E. T., Belk, D., Ferren Jr., W. R., and Ornduff, R., Proc. from a 1996 Conference, California Native Plant Society, 19-21 June, Sacramento, CA, 15-23, 1998.

Strahorn, A. T., Mackie, W. W., Westover, H. L., Holmes, L. C., and Van Duyne, C.: Soil survey of Marysville Area, California, US Department of Agriculture, Bureau of Soils, Washington, D.C., 1911.
Sweet, A. T., Warner, J. F., and Holmes, L. C.: Soil Survey of the Modesto-Turlock Area, California, With a Brief Report on a Reconnaissance Soil Survey of the Region East of the Area, US Dept. of Agriculture, Bureau of Soils, Washington, D.C., 1909.

TBI - The Bay Institute: From the Sierra to the Sea: The Ecological History of the San Francisco Bay-Delta Watershed, The Bay Institute of San Francisco, Novato, CA, USA, 1998.

Thompson, K.: The settlement geography of the Sacramento-San Joaquin Delta, California, PhD Dissertation, Stanford University, 1957.

Thompson, K.: Riparian forests of the Sacramento Valley, California, Ann. Assoc. Am. Geogr., 3, 294-315, 1961.

Thompson, K.: Riparian forests of the Sacramento Valley, California, in: Riparian Forests in California: Their Ecology and Conservation, No. 15, edited by: Sands, A., A Symposium Sponsored by Institute of Ecology, University of California, Davis and Davis Audubon Society, Institute of Ecology Publication, Davis, 1977.

Thomson, J. R., Kimmerer, W. J., Brown, L., Newman, K. B., MacNally, R., Bennett, W. A., Feyrer, F., and Fleishman, E.: Bayesian change-point analysis of abundance trends for pelagic fishes in the upper San Francisco Estuary, Ecol. Appl. 20, 1431-1448, 2010.

Thorne, J. H., Morgan, B. J., and Kennedy, J. A.: Vegetation change over sixty years in the Central Sierra Nevada, California, USA, Madroño, 3, 223-237, 2008.

Vaghti, M. G. and Greco, S. E.: Riparian vegetation of the Great Valley, in: Terrestrial Vegetation of California, 3rd Edn., edited by: Barbour, M. G., Keeler-Wolf, T., and Schoenherr, A. A., University of California Press, Berkeley, 425-455, 2007.

Warner, R. E. and Hendrix, K. M.: Riparian Resources of the Central Valley and California Desert, Final Draft, Department of Fish \& Game, Sacramento, 1985.

Watson, E. B., Glassey, T. W., Storie, R. E., and Cosby, S. W.: Soil survey of the Chico area, California, Series 1925, Number 4, US Department of Agriculture, Bureau of Chemistry and Soils, Washington, D.C., 1929.

Whipple, A. A., Grossinger, R. M., Rankin, D., Stanford, B., and Askevold, R. A.: Sacramento-San Joaquin Delta Historical Ecology Investigation: Exploring Pattern and Process, Publication 672, San Francisco Estuary Institute (SFEI) - Aquatic Science Center, Richmond, CA, 2012.

Williamson, A. K., Prudic, D. E., and Swain, L. A.: Ground-water flow in the Central Valley, California, US Geological Survey Professional Paper 1401-D, United States Government Printing Office, Washington, D.C., USA, 1989.

Williamson, R. S.: Report of exploration in California for railroad routes to connect with the routes near the 35 th and $32 \mathrm{~d}$ parallels of north latitude, in: Reports of Explorations and Surveys, to Ascertain the Most Practicable and Economical Route for a Railroad from the Mississippi River to the Pacific Ocean, United States War Dept., United States Army, Washington, 1853.

Zedler, P. H.: Vernal pools and the concept of "IsolatedWetlands", Wetlands, 3, 597-607, 2003. 